\title{
2o \\ FANATISMENS SEIER? \\ JIHADISMENS FRAMMARSJ I \\ DEN ARABISKE VERDENEN
}

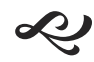

Jihadismens frammarsj som ideologi og global opprørsbevegelse er blant de mest fremtredende utviklingstrekkene i Midtøsten de siste 15 årene. Hvordan har jihadistbevegelsen kunnet vokse seg så mye sterkere i tidsrommet etter II. september-angrepene, samtidig som USA og dets allierte i regionen har brukt enorme ressurser på nettopp å nedkjempe opprørsgrupper og nettverk knyttet til al-Qaida og den bredere jihadistbevegelsen?

BRYNJAR LIA

$\mathrm{D}$ enne artikkelen forsøker å belyse dette paradokset gjennom en analytisk beskrivelse av jihadistbevegelsens historiske utvikling og dens underliggende drivkrefter. ${ }^{1}$ Faktorer som folkelig støtte, dens transnasjonale karakter og sosiale forankring tillegges særlig vekt. De gjengse oppfatningene av jihadistgrupper som isolerte terrorceller, marginale undergrunnsbevegelser og fanatiske, kultlignende grupper er lite fruktbare modeller for å analysere jihadistbevegelsen i dag. Bevegelsen må heller forstås som en global opprørsbevegelse med sympati fra betydelige deler av befolkningen i den arabiske verden og med støtte fra et bredt globalt nettverk av dedikerte tilhengere. Jihadistbevegelsen har vist en oppsiktsvekkende evne til å tiltrekke seg store antall fremmedkrigere, mobilisere betydelige finansielle ressurser, og administrere sivilbefolkning og byråkrati i sine territoriale «protostater». Denne bevegelsen kan ikke bekjempes med militærmakt alene. Dersom man skal ha håp om å meisle ut en virkningsfull strategi for å begrense jihadistbevegelsens videre utbredelse, må man i større grad anerkjenne at dette er en global geriljabevegelse med sosial og folkelig forankring, og at den representerer ikke bare en terrortrussel, men også et politisk opprør fundert på reell politisk og sosial misnøye.

\section{EN KONTRAPRODUKTIV KRIG}

Et av de mest overraskende utviklingstrekkene i kjølvannet av ir.9.-angrepene og starten på den usA-ledede globale terrorkrigen ( Global War on Terror») ${ }^{2}$ er jihadistbevegelsens ${ }^{3}$ motstandsdyktighet. Ikke bare har bevegelsen overlevd. Den har faktisk ekspandert - både i og utenfor Midtøsten - og vunnet en utbredelse som hadde vært utenkelig i 200r. Denne dramatiske veksten har funnet sted til tross for at det ble satt inn enorme økonomiske og militære ressurser for å forhindre en slik utvikling. En usA-ledet internasjonal koalisjon har, i samarbeid med regionale partnere 


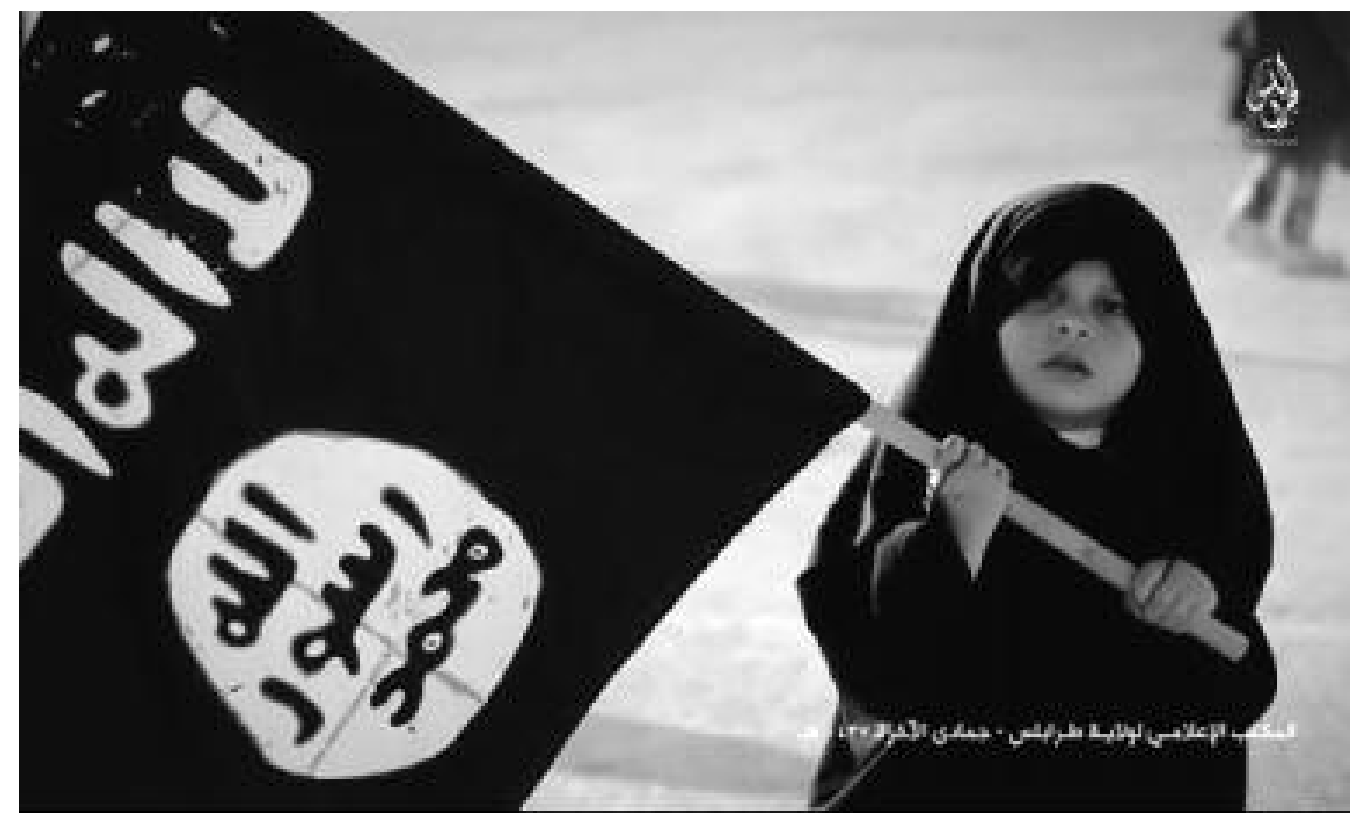

Skjermdump fra en film produsert av ISIS Libya, 2016.

i Midtøsten, investert massivt i terror- og opprørsbekjempelse, og har tatt i bruk alle tilgjengelige virkemidler, inkludert virkemidler som ligger langt utenfor folkerettens prinsipper. Til tross for denne kostnadskrevende og omfattende innsatsen har jihadistbevegelsen i løpet av de siste femten årene opplevd en voldsom ekspansjon, både som militær geriljastyrke og global terrortrussel. I tillegg har bevegelsens ideologi, jibadismen, ${ }^{4}$ vunnet en dominerende plass som vår tids kanskje fremste voldelige opprørsideologi. I skrivende stund er Den islamske staten (også kjent under dets forrige navn, Den islamske staten i Irak og Sham [Levanten] (IsIs eller ISIL)) i ferd med å miste betydelige territorier i deres kjerneområder i Syria og Irak, samt i deres viktigste regionale provins i Libya. Samtidig har organisasjonen vist evne til å holde stand mot en stor internasjonal koalisjon og en intens luftkrig som allerede har vart $i$ to år. Is Is har videre vært i stand til å gjennomføre en lang rekke blodige interna- sjonale terrorangrep utenfor Syria og Irak i en kampanje som har krevd over I200 menneskeliv på fem kontinenter mellom september $20 \mathrm{I} 4 \mathrm{og}$ juli 20I6. Et raskt blikk på noen indikatorer på jihadistbevegelsens militære styrke og evne til territoriell konsolidering i Midtøsten viser også en faretruende oppadgående trend de siste femten årene (jamfør figur 4 og 5).

I løpet av de siste årene har det blitt mer og mer tydelig at den internasjonale innsatsen for å bekjempe al-Qaida og dets lokale og regionale avleggere har vært en kolossal fiasko. ${ }^{6}$ Jihadistbevegelsens militære styrke, dens ideologiske tiltrekningskraft, rekrutteringsgrunnlag og finansieringskilder er fremdeles intakt, og har på flere områder økt betydelig. Noe av antiterrorinnsatsen har riktignok hatt en klar effekt, slik som usAs intensiverte opprørsbekjempelse i Irak i andre halvdel av 2000-årene, deradikaliseringsprogrammene i Egypt i siste halvdel av I990årene, og i Libya og Saudi-Arabia i 200o-årene. ${ }^{7}$ 
Disse fremskrittene har imidlertid vært kortvarige, og i alle de nevnte landene - med mulig unntak av Saudi-Arabia - har jihadistbevegelsen vokst seg sterkere. Man har ikke nådd målet om å redusere jihadisttrusselen fra et globalt strategisk anliggende til et ordinært lokalt sikkerhetsproblem. I det store og det hele er hovedinntrykket at den usA-ledete "globale kampen mot terror» har virket mot sin hensikt. I etterpåklokskapens lys synes det klart at terrorkrigen - der bruk av «kinetiske» virkemidler (en vanlig eufemisme for dødelig militærmakt) har vært det dominerende verktøyet - har lagt grunnlaget for en jihadistisk rekrutteringsbonanza.

Til tross for gjentatte oppfordringer om å flytte tyngdepunktet i den globale kampen mot terror over på «myke maktmidler» og større bruk av sivilrettslige og juridiske metoder, har militærmakt og krigens logikk forblitt dominerende. Det sistnevnte har undergravet troverdigheten til de myke tiltakene, herunder innsatsen mot radikalisering og voldelig ekstremisme. ${ }^{8}$ De siste årene har stadig flere muslimske majoritetsland opplevd vestligledete intervensjoner og militært nærvær - både i liten og stor skala. Blant disse landene finner vi Afghanistan, Pakistan, Irak, Syria, Jemen, Somalia, Mali og en rekke andre land. I kjølvannet av etableringen av Joint Special Operation Command (Jsoc), gikk usA i spissen for en omfattende kampanje for målrettede drap av «mistenkte terrorister» $\mathrm{i}$ et titalls land $\mathrm{i}$ flere verdensdeler. Den såkalte «dronekrigen» innebar at amerikanske ubemannede fly avfyrte missiler mot mistenkte jihadister, deres treningsleirer og gjemmesteder i en rekke ulike konfliktområder fra Afghanistan og Pakistan til krigssoner i Afrika og Midøsten, i første rekke Jemen og Somalia. ${ }^{9}$ I tillegg til disse grenseoverskridende militæroperasjonene ble det opprettet et globalt nettverk av hemmelige fengsler for mistenkte terrorister, hvor avhørsteknikkene var brutale og ofte langt over grensen for hva som er tortur.

Selv om man bør være varsom med å trekke absolutte konklusjoner vedrørende langtidseffektene av den globale terrorkrigen, er det mye som tyder på at de negative konsekvensene har vært meget betydelige. En av de utilsiktete bieffektene er spredningen av lokale og regionale utgaver av terrorkrigen. I tiden etter 200I, og særlig etter de arabiske folkeopprørene i 20I0-20II, har flere av statene i Midtøsten gjort terrorkrigsdiskursen til sin egen og brukt denne som begrunnelse for militær inngripen mot naboland eller mot opprørsgrupper på andre staters territorium. ${ }^{10}$ Selv om dette fenomenet slettes ikke er nytt, jamfør Israels og Tyrkias historiske praksis med «militære sikkerhetssoner», synes likevel terskelen for bruk av slik militærmakt å ha blitt senket. Eksemplene er mange: den pågående saudiledete luftkampanjen mot houthiopprørerne i Jemen, de egyptiske luftangrepene i Libya til støtte for general Heftars milits, Jordans bombing av Isıs-mål i Syria, og Iran og (deres libanesiske allierte) Hizbollahs deployering av store militsstyrker i den syriske borgerkrigen.

\section{DEN TAPTE KAMPEN OM HJERTER OG SINN}

En sterkt medvirkende faktor til at terrorkrigen har virket mot sin hensikt er at militærmakt $i$ antiterrorens navn så ofte forårsaker sivile tap og skader. Dermed skal det lite til å overbevise publikum om at det i realiteten foregår en krig mot islam, ikke mot terror. Sistnevnte påstand gjentas til det kjedsommelige $i$ jihadistisk propaganda. For å belyse denne sammenhengen bedre kan det være hensiktsmessig å studere tilgjengelige meningsmålinger der oppslutningen om jihadistbevegelsen er blitt tallfestet. Slike målinger er gjort siden begynnelsen av 2000-årene. Her fremgår det klart at forsøkene på å øke folkelig støtte til kampen mot al-Qaida vært 


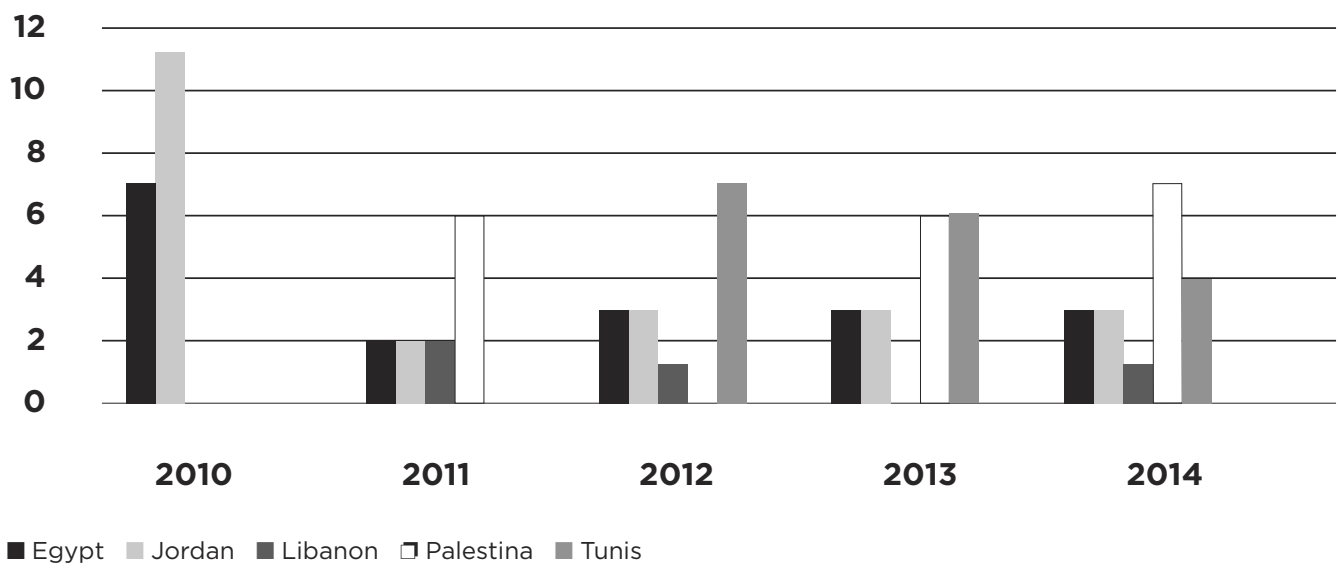

Figur 1: Meningsmålinger om al-Qaida. Kolonnene viser (i prosent) andelen av respondenter som uttrykker en «svært positiv [very favourable]» mening om al-Qaida i utvalgte arabiske land.14

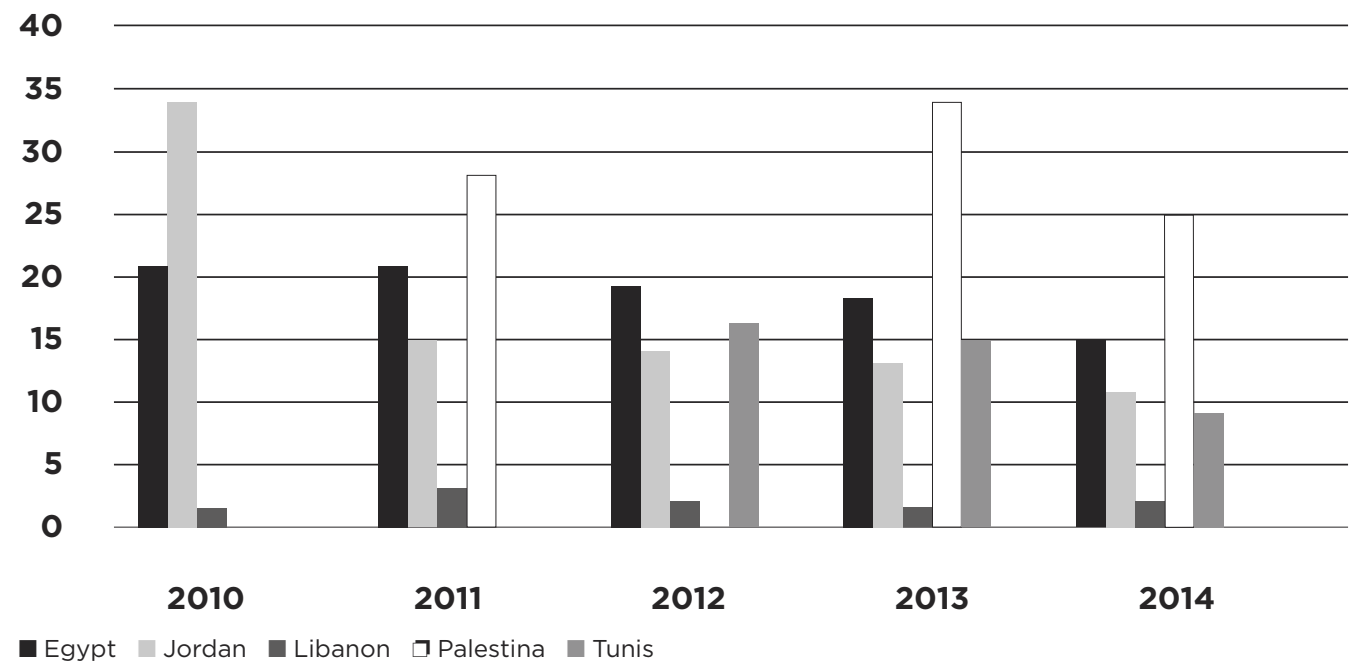

Figur 2: Meningsmålinger om al-Qaida. Kolonnene viser (i prosent) andelen av respondenter som uttrykker enten en «svært positiv [very favourable]» eller en «til en viss grad positiv [somewhat favourable]» mening om alQaida i utvalgte arabiske land..$^{15}$ 
relativt mislykket. Meningsmålingene viser oppsiktsvekkende høye tall hva gjelder sympati for jihadistene og deres voldsaksjoner (jamfør figur nr. I, 2 og 3 nedenfor). Selv etter fremveksten av Isis, den mest voldelige eksponenten av jihadisme, vekker ideologien fortsatt sympati blant millioner av mennesker i regionen.

Selv om tallene på sympatisører har gått noe ned fra de ekstremt høye nivåene etter invasjonen av Irak i $2003,{ }^{11}$ har jihadistene fortsatt en betydelig tilhengerskare. I flere land i regionen, særlig Egypt, Jordan, Palestina og Tunisia, utgjør respondentene som uttrykker «svært positiv oppfatning» eller «noe positive oppfatning om alQaida» en tosifret prosentandel av totalen. Sympatien for isis er noe lavere, men selv overfor denne gruppen finner man at mellom to og ti prosent av respondentene i Palestina, Algerie, Mauritania, Sudan, Egypt og Marokko utrykker «svært positive» holdninger. Det samlede tallet for regionen som helhet er tre prosent, mens tallet er

Flere millioner mennesker i regionen har sympati for og kan tenkes å støtte IsIs og/eller al-Qaida i varierende grad.

så høyt som syv prosent når man inkluderer respondenter som har en "positiv oppfatning til en viss grad» til verdens mest dødelige jihadistorganisasjon. Med et estimert befolkningstall på 355 millioner i Midtøsten og Nord-Afrika, viser målingene at flere millioner mennesker i regionen har sympati for og kan tenkes å støtte Isis og/eller al-Qaida i varierende grad. Libanon er et unntak med sin svært lave oppslutning om isis og alQaida.

Gitt at sympatisører har en tendens til å være konsentrert i visse bydeler og lokalsamfunn, er det stor sannsynlighet for at jihadistopprørerne finner friområder der den lokale oppslutningen er såpass stor at de kan operere som «fisken i vannet», et kjent begrep fra maoistisk geriljakrigslitteratur. ${ }^{12}$ Med andre ord, den folkelige støtten overskrider en kritisk terskel ved at den lokale befolkningen er villig til å strekke seg langt for å hjelpe, beskytte og ikke minst glorifisere «mujahideen» som gjemmer seg blant dem. Fremstillingen av jihadistbevegelsen som en marginal undergrunnsbevegelse med små isolerte terrorceller eller en ekstremist kultlignende bevegelse som er hatet og foraktet av den omkringliggende befolkningen er i mange tilfeller altså ikke korrekt. I stedet har jihadistene maktet å posisjonere seg som en opprørsgruppe med et solid, om enn sterkt varierende, fotfeste blant massene. ${ }^{13}$

\section{JIHADISTBEVEGELSENS EKSPANSJON}

Fremveksten av en stadig sterkere jihadistbevegelse, både i form av nye grupperinger og gjennom ekspansjon av etablerte nettverk, har vært tydeligst i tiden etter de arabiske folkeopprørene i 201 . Den saudiledete kontrarevolusjonen, som knuste opprøret i Bahrain og bidro til militærkuppet i Egypt, og eskaleringen fra folkeopprør til borgerkrig i Syria, Libya og Jemen, har på ulike måter skapt vekstvilkår og større handlingsrom for jihadistene. Det er imidlertid viktig å bemerke at den regionale ekspansjonen (i Midtøsten og NordAfrika) av grupper tilknyttet al-Qaida kom lenge før utbruddet av den arabiske våren, men etter 20II har ekspansjonen skutt kraftig fart og skapt et mye tyngre nærvær av jihadistgrupper enn tilfellet var for 15 år siden.

Kort tid etter usAs invasjon av Irak i mars 2003 gjorde al-Qaidas første regionale avdeling i Midtøsten seg gjeldende: Al-Qaida på Den arabiske halvøy (AQAP) sto bak en langvarig bombekampanje i Saudi-Arabia fra 2003 inntil gruppen ble desimert i 2006. ${ }^{17}$ Omtrent parallelt med dette ble en ny gren i al-Qaida-nettverket grunnlagt i 


\begin{tabular}{|c|c|c|c|c|c|c|c|}
\hline Jordan & 1 & 11 & & & & & 96 \\
\hline Tunis & 1 & 12 & & & & & 94 \\
\hline Algerie & 5 & 4 & & 7 & 14 & & 69 \\
\hline Saudi-Arabia & 1 & 12 & 6 & 6 & & & 89 \\
\hline Sudan & 5 & & 6 & 3 & 12 & & 72 \\
\hline Irak & 1 & 11 & 4 & & & & 93 \\
\hline Palestina & 2 & 4 & 5 & & 11 & & 76 \\
\hline Kuwait & 1 & 4 & 3 & 10 & & & 80 \\
\hline Libanon & 1 & 8 & & & & & 91 \\
\hline Egypt & 3 & 6 & & 7 & 11 & & 73 \\
\hline Marokko & 3 & 5 & & 7 & 15 & & 68 \\
\hline Mauritania & 10 & & 10 & 0 & 6 & 12 & 62 \\
\hline Snitt & 3 & 4 & 4 & & 9 & & 80 \\
\hline
\end{tabular}

Veldig positiv

Litt positiv $\square$ Nøytral Litt negativ $\square$ Svært negativ

Figur 3: Meningsmålinger om Den islamske staten (ISIS) i arabiske land. Kolonnene viser (i prosent) andelen av respondenter som uttrykker en «svært positiv», "positiv til en viss grad», «nøytral», «negativ til en viss grad» eller «svært negativ» oppfatning [opinion] om ISIS. ${ }^{16}$

Irak. Senhøsten 2004 skiftet jihadistgruppen Monoteisme og jihad navn til Al-Qaida i Irak (AQI), og dets leder avla troskapsed til bin Laden. ${ }^{18}$ Gruppen ble raskt den dominerende aktøren i det sunniarabiske opprøret mot UsA og det nye irakiske regimet. AQI er den direkte forløperen til ısıs. I Nord-Afrika fikk al-Qaida også et sterkere fotfeste på 2000-årene. I 2006-2007 ble en lokal algerisk jihadistgruppe omdannet til al-Qaidas regionale avdeling med navnet AlQaida i det islamske Maghreb (AQIM). Organisasjonen utvidet operasjonsområdet sitt til det meste av Nord-Afrika og Sahel-regionen, og har i dag mange lokale avleggere.

I Jemen så vi en noe tilsvarende konsolidering av al-Qaida-lojale grupperinger. Lokale jihadistmiljøer og restene av den saudiarabiske AQAP- gruppen dannet en slagkraftig Jemen-basert organisasjon i siste halvdel av 2000-årene. Fra 2009 ble grupperingen betraktet som al-Qaidas fremste spydspiss i internasjonal terrorisme. ${ }^{19}$ Sist, men ikke minst, den somaliske opprørsgeriljaen Shabaab, også kjent som Den islamske ungdomsbevegelsen, ble dannet allerede på midten av 2000-årene, og opererte i begynnelsen som en milits til støtte for Den islamske domstolsunionen. ${ }^{20}$ Sistnevnte styrte størstedelen av Somalia $\mathrm{i}$ en periode frem til en UsA-støttet etiopisk invasjon i 2006 igjen førte landet ut i borgerkrig. Mot slutten av 2000-årene beveget Shabaab seg stadig nærmere al-Qaida både ideologisk og militært. I 20I2 ble islamistgeriljaen utnevnt til al-Qaidas offisielle avdeling på Afrikas horn. 


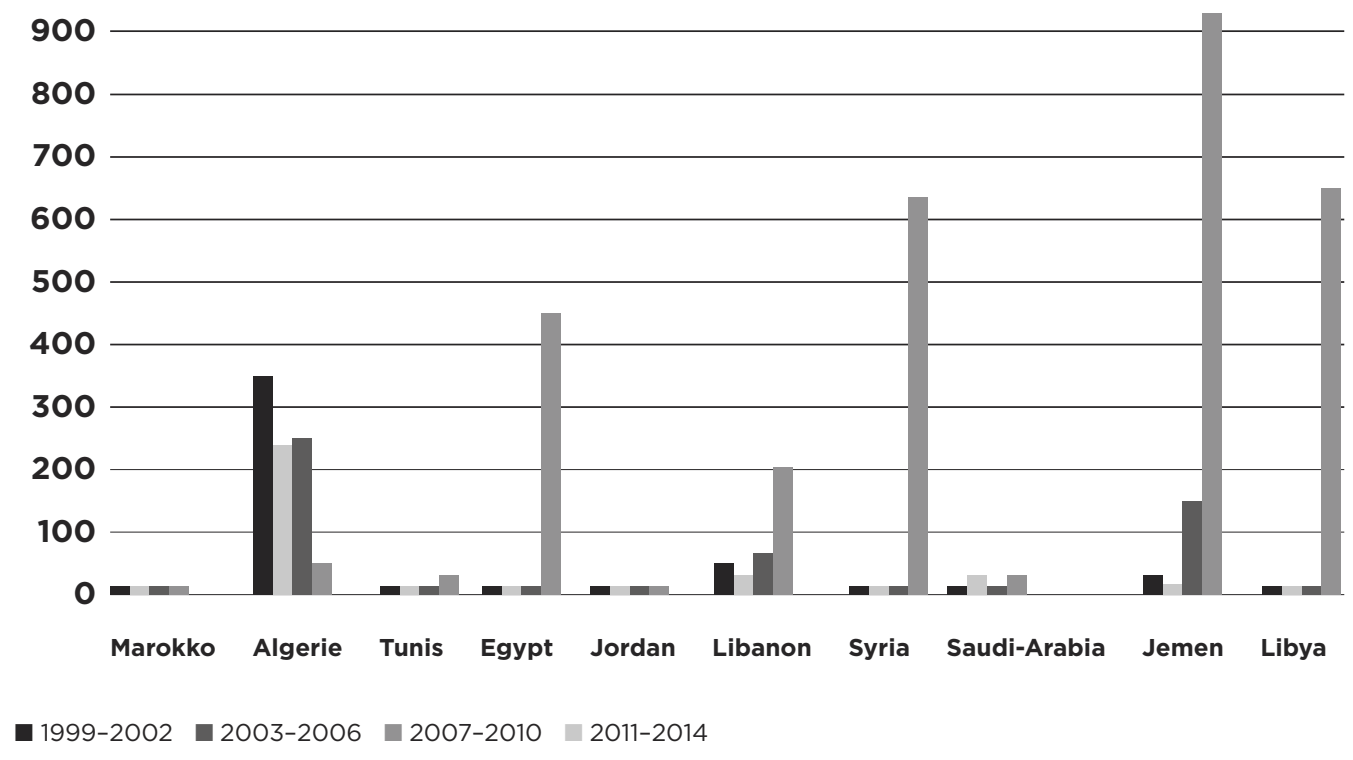

Figur 4: Antall terrorhendelser i Midtøsten mellom 1999 og 2014, basert på data fra Global Terrorism Database.

Som vist ovenfor var altså etableringen av alQaida-avdelinger i Jemen, Nord-Afrika, Irak og Somalia i noen grad et resultat av en omdøping, restrukturering og konsolidering av allerede eksisterende islamistiske militante grupper. $^{21}$ Regionaliseringen av al-Qaida betydde derfor at den lokale konteksten og lokale konfliktlinjer ble viktigere for jihadistbevegelsen. De nye al-Qaidaavdelingene var imidlertid ikke kun navneskifter. Al-Qaidas ideologiske narrativer og fremgangsmåter ble adoptert, om enn med betydelige lokale tilpasninger. I sum var denne utvikling særdeles viktig ettersom den bidro til en bredere mobilisering av militante islamistgrupper rundt en global jihadistisk agenda.

Jihadistbevegelsenes utbredelse i dag har også en forhistorie som strekker seg lengre bakover. Militante islamistgrupper har spilt en sentral rolle i Midtøsten helt siden I970-årene, og i perioder har denne typen opprørsgrupper representert en betydelig utfordring for de sittende regimene. Et langvarig islamistopprør rystet Hafiz al-Asads regime i Syria fra slutten av I970-årene og frem til 1982. ${ }^{22}$ Fra 1980-årene og frem til 1997 førte egyptiske militante islamister en lavintensitetskrig mot Mubaraks regime. ${ }^{23}$ Libya var preget av en tilsvarende voldskampanje på midten av I990årene. Det var imidlertid i Algerie at væpnete jihadistopprør fikk størst omfang. Etter militærkuppet i landet i januar 1992 brøt det ut omfattende sammenstøt og terrorhandlinger der militante islamister sto i spissen for opprørerne. Konflikten eskalerte til en ødeleggende borgerkrig; mer enn hundre tusen mennesker ble drept. ${ }^{24}$

Ved inngangen til det nye millenniet hadde imidlertid disse lokale islamistopprørene blitt nedkjempet. Jihadisme var ikke lenger en altomfattende sikkerhetsutfordring for de autoritære regimene i Alger, Damaskus, Tripoli eller Kairo. Arabiske militante islamister satt fengslet eller hadde søkt tilflukt andre steder. ${ }^{25}$ Det var derfor ingen tilfeldighet at Ir. september-angrepene ikke 
ble organisert fra Midtøsten, men fra Afghanistan, som ved utgangen av I990-årene hadde blitt et tilfluktssted, samlingspunkt og militærbase for militante islamister fra hele verden.

I den første tiden etter II. september $200 \mathrm{I}$ rettet den USA-ledete krigen mot terror seg mot Afghanistan. Okkupasjonen av Irak fra mars 2003 viste seg imidlertid å bli et viktig vendepunkt. Den banet vei for et bredt anlagt sunni-arabisk opprør der al-Qaida fikk innpass og der en arena ble skapt for dannelsen av al-Qaidas viktigste avdeling i den arabiske verden. Det var på mange måter et paradoks at Irak skulle bli et så sentralt utgangspunkt for al-Qaidas regionale ekspansjon. I motsetning til flere andre arabiske land hadde ikke Irak hatt noe jihadistisk tilstedeværelse av betydning med unntak av en liten territoriell enklave nær grensen mot Iran i den kurdisk-kontrollerte delen av Nord-Irak. Der hadde kurdiske jihadister holdt til i lengre tid, og der ble Ansar al-Islambevegelsen dannet i desember 200 I under mulla Krekars ledelse. Denne gruppens hovedkvarter og leirer ble det aller første målet for den amerikanske luftkampanjen som innledet Irak-krigen våren 2003. Forventningene om den forestående amerikanske invasjonen og en kommende væpnet motstandskamp mot amerikanerne på okkupert arabisk jord, la grunnlaget for at mange fremmedkrigere strømmet til Irak fra Afghanistan og fra store deler av den arabiske verden, godt hjulpet av syriske myndigheter.

Diskursen til al-Qaida-ideologer og tilfeldige sympatisører på jihadistiske webfora på hele 2000-årene levner liten tvil om at selve drivkraften bak den økende omfavnelsen av al-Qaidas agenda og verdensanskuelse var den nye geopolitiske virkeligheten i Midtøsten, nærmere bestemt den UsA-ledete militære okkupasjonen av Irak og Afghanistan og UsAs militære nærvær og rolle i regionen som helhet. Selv om jihadistenes tekster, taler og nettskriverier er ikledd en utpreget religiøs språkdrakt, er kallet til motstand mot okkupasjonen allestedsnærværende. Man kan derfor hevde at jihadismen i dag representerer en form for antiimperialisme kombinert med islamsk nasjonalisme (nasjonen forstås her som det islamske fellesskapet, ummaen, ikke nasjonalstatene). Historisk sett har antikolonialistisk motstand manifestert seg under mange ulike ideologiske avskygninger i den arabiske verden de siste to hundre årene, både i lokale, panarabiske eller panislamske versjoner. Det er sannsynligvis denne panislamske nasjonalistiske mobiliseringen som har drevet de unge i hendene på jihadismen, ikke religiøs iver, fordommer og fremmedfrykt. $\mathrm{Og}$ det er denne tette assosieringen med nasjonalistisk mobilisering som har gjort jihadistbevegelsen i stand til å ekspandere fra en undergrunnsbevegelse til en bredt anlagt opprørsbevegelse.

I kjølvannet av de arabiske folkeopprørene i 20II har regionen vært vitne til en skarp, men ujevn, økning i politisk vold. Som det fremgår av tabellene nedenfor, viser data fra Global Terrorism Database (GTD) en økning i de fleste landene, med unntak av Marokko og Algerie. Økningen er dramatisk i de landene som var mest berørt av den arabiske våren: Egypt, Libya, Syria, Tunisia og Jemen. Endringene har vært mye mindre tydelige i de konservative monarkiene Jordan, Marokko og Saudi-Arabia, der kongemakten har kvalt revolusjonstrangen med en kombinasjon av større velferdsgoder, lønnsøkninger, løfter om politiske reformer, politimakt og, ikke minst, trusselen om krig og kaos. ${ }^{26}$

Det er interessant å merke seg at i det eneste arabiske landet hvor de arabiske folkeopprørene lyktes i å skape en varig overgang til demokratisk styre, Tunisia, har myndighetene maktet å demme opp for voldsspiralen til tross for tilstedeværelsen av en betydelig jihadistbevegelse. ${ }^{27} \mathrm{I}$ de andre landene hvor den arabiske våren fikk sitt sterkeste 
uttrykk, men uten at de revolusjonære demonstrantene klarte å kaste de sittende regimene, har demonstrasjonene blitt fortrengt av en kombinasjon av voldelig opprør og ekstrem statlig voldsutøvelse som grenser til statsterror. ${ }^{28} \mathrm{I}$ tre av landene - Syria, Libya og Jemen - har folkeopprørene utviklet seg til borgerkriger. Det samlete resultatet har vært meget høye nivåer av vold og en betydelig smitteeffekt på nabolandene Libanon, Jordan og Saudi-Arabia. ${ }^{29}$ Selv Irak, som allerede hadde et svært høyt nivå av politisk vold fra midten av 200o-årene, opplevde en økning etter 20Ir. Et unntak fra den generelle oppadgående trenden er Algerie, et land som var rammet av en meget blodig borgerkrig på 1990årene. Der har voldsnivået vært hovedsakelig nedadgående siden tidlig i 200o-årene.

Numerisk data gjør en dårlig jobb i å formidle helheten og nyansene $\mathrm{i}$ jihadistbevegelsens endring $\mathrm{i}$ den arabiske verden etter 20II. Den kvantitative dimensjonen er bare et fragment av transformasjonsprosessen. I kjølvannet av den arabiske våren vokste det frem et mye mer variert landskap av jihadistgrupper. Bevegelsens veteraner og deres sympatisører opererte ikke lenger innenfor rammene av hemmelige celler og skjulte nettverk, men beveget seg i større grad enn før ut i det sosiale rommet og det nye politiske landskapet som revolusjonene hadde skapt. Jihadister begynte å operere innenfor en rekke nye felter, fra religiøs forkynning ( $\left.d a^{\prime} w a\right)$ og sosialt veldedighetsarbeid, til demonstrasjoner og gateaktivisme. I flere land opererte de som nabolagspoliti og som selvoppnevnte håndhevere av sharia. Svekkelsen av de sittende arabiske regimene i Tunisia, Libya, Egypt og Jemen skapte et nytt handlingsrom for jihadistene. De grep muligheten og etablerte nye organisasjoner med offentlige kontorer, med deltakelse i politisk aktivisme, herunder sivil ulydighet-aksjoner og offentlige demonstrasjoner.
Den mest profilerte delen av denne nye aktivismen var Ansar al-Shari'a-bevegelsene, et nettverk av militante salafistgrupperinger hvis oppfordringer til væpnet kamp ble akkompagnert av en utstrakt ideologisk pragmatisme med hensyn til når og hvor væpnet jihad var obligatorisk og prioritert. Deres nærvær var mest tydelig i Tunisia og Libya i 20I2-20I3. I kjølvannet av flere voldsaksjoner ble Ansar al-Shari'a Tunisia forbudt og deres utestengelse fra den politiske arenaen førte til et mer eksplisitt fokus på militære virkemidler i kampen mot jihadisme. ${ }^{31} \mathrm{I}$ Jemens tilfelle var Ansar al-Shari'a også knyttet til den eksisterende al-Qaida-grenen og fungerte som dens ansikt utad. Utviklingen i den første perioden etter 20II varslet med andre ord om fremveksten av et mer variert landskap av jihadistbevegelser, og syntes å antyde en fremtidig politisering og mulig temming av de mest aktive jihadistene. Utsiktene til en slik utvikling var ikke basert på naive og urealistiske forventinger. Siden I990-årene hadde regionen vært vitne til en rekke vellykkede demilitariserings- og/eller deradikaliseringsprosesser hvor væpnede islamistiske grupper, fraksjoner og ideologer i Marokko, Algerie, Libya, Egypt, Saudi-Arabia, Jemen og Libanon hadde sluttet fred med regimene. I noen tilfeller hadde også sentrale ideologiske stemmer i jihadistbevegelsene gått med på å revidere sine radikale programmer. ${ }^{32}$

Den økte involveringen av jihadistgrupper i ikke-militære aktiviteter i kjølvannet av den arabiske våren, viser at selv al-Qaida-tilknyttede grupper kan være mottagelige for idéen om en overgang til det sivile politiske liv. I denne forbindelse var dannelsen av frontorganisasjoner en viktig utvikling fordi det kunne signalisere en langsiktig ambisjon om å ekspandere fra geriljaorganisasjon og terrornettverk til en politisk aktør. AQAPs dannelse av Ansar al-Sharía og senere samarbeid med sivile organisasjoner som $\mathrm{Ha}^{-}$ 


\section{JIHADISTISKE PROTOSTATER I DEN ARABISKE VERDENEN ETTER 2011}

\begin{tabular}{|c|c|c|c|c|c|}
\hline Navn & Sted & Periode & $\begin{array}{l}\text { Territoriell } \\
\text { kontroll }\end{array}$ & $\begin{array}{l}\text { Sivile } \\
\text { institusjoner }\end{array}$ & $\begin{array}{l}\text { Fremmed- } \\
\text { krigere }\end{array}$ \\
\hline $\begin{array}{l}\text { AQAP Ansar } \\
\text { al-Shari'ah }\end{array}$ & $\begin{array}{l}\text { Sørlige Jemen/ } \\
\text { Ayban-provinsen } \\
\text { (Zinjibar, Jaar, } \\
\text { Shuqrah etc.) }\end{array}$ & 2011-2012 & $\mathrm{Ja}$ & $\mathrm{Ja}$ & Ja, lite antall. \\
\hline $\begin{array}{l}\text { AQIM Ansar } \\
\text { al-Dine, MUJAO }\end{array}$ & $\begin{array}{l}\text { Nord-Mali/ } \\
\text { Timbuktu, } \\
\text { Kidal, Gao etc. }\end{array}$ & Mars 2012-2013 & $\mathrm{Ja}$ & $\mathrm{Ja}$ & Ja, lite antall. \\
\hline Jabhat al-Nusra & $\begin{array}{l}\text { Områder i nord- } \\
\text { vestlige og } \\
\text { sørvestlige Syria, } \\
\text { som oftest i sam- } \\
\text { arbeid med } \\
\text { andre syriske } \\
\text { opprørsgrupper. }\end{array}$ & $2012-$ & $\mathrm{Ja}$ & $\mathrm{Ja}$ & $\begin{array}{l}\text { Ja, men langt } \\
\text { færre enn ISIS. }\end{array}$ \\
\hline ISIS/IS & $\begin{array}{l}\text { Store deler av } \\
\text { nordøstlige Syria } \\
\text { og vestlige Irak. }\end{array}$ & 2013- & $\mathrm{Ja}$ & $\mathrm{Ja}$ & $\begin{array}{l}\text { Ja, svært høyt } \\
\text { antall. }\end{array}$ \\
\hline $\begin{array}{l}\text { MSSI, Ansar } \\
\text { al-Shari'ah Libya } \\
\text { og ISIS-provinser }\end{array}$ & $\begin{array}{l}\text { Libya, distrikter i } \\
\text { Benghazi, Derna } \\
\text { (2014) og Sirte } \\
\text { (siden medio } \\
\text { 2015). }\end{array}$ & 2014- & $\mathrm{Ja}$ & $\mathrm{Ja}$ & $\begin{array}{l}\text { Ja, svært høy } \\
\text { prosentandel av } \\
\text { ISIS-krigerne, de } \\
\text { fleste fra Maghreb } \\
\text { eller subsaharisk } \\
\text { Afrika. }\end{array}$ \\
\hline $\begin{array}{l}\text { Bayt Ansar } \\
\text { al-Baqdis - ISIS' } \\
\text { Sinai-provins }\end{array}$ & Egypt/Sinai & 2011- & Nei & ? & Ja, lite antall. \\
\hline $\begin{array}{l}\text { AQAP Ansar } \\
\text { al-Shari'ah } \\
\text { Hadramawts } \\
\text { Sønner }\end{array}$ & $\begin{array}{l}\text { Sørlige Jemen, } \\
\text { inkludert } \\
\text { Mukallah, } \\
\text { Zinjibar og Jaar. }\end{array}$ & 2015- & $\mathrm{Ja}$ & $\begin{array}{l}\text { Ja, et sivilt } \\
\text { råd utnevnt }\end{array}$ & Ja, lite antall. \\
\hline
\end{tabular}

Figur 5: Utbredelsen av jihadistiske protostater i den arabiske verden etter 2011. 
dramawts Sønner i 20I5, viser det voksende samspillet mellom AQAP og det jemenittiske samfunnet på lokalt nivå i det sørlige Jemen. Dette var ikke en utvikling isolert til Jemen. I tiden etter 2or begynte flere jihadistbevegelser i regionen å opptre som «sosialt integrerte opprørsgrupper» som aktivt søkte folkelig støtte. ${ }^{33}$ Dette frieriet til massene var ikke ukjent i jihadistisk ideologisk diskurs. ${ }^{34}$ Det som imidlertid var nytt, var de nye mulighetene til å praktisere dette, til å vinne innflytelse som politiske og territorielle aktører og til å bevege seg utover det monotone fokuset på væpnet kamp. Man var vitne til en ny generasjon jihadister som strebet mot å danne selvstyrte, jihadistiske protostater eller «emirater», et fenomen som skjøt voldsom fart etter 20II. I femårsperioden mellom $201 \mathrm{I} \mathrm{og} 2016$ opprettet

\section{Jihadistiske opprørsgrupper er ofte} avhengige av eksterne støttenettverk som kanaliserer midler til krigssonen.

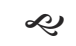

jihadister flere territoriale protostater enn de hadde gjort i løpet av de 23 årene mellom alQaidas grunnlegging i I988 til 20II (se figuren nedenfor). ${ }^{35}$

De nye jihadistiske ministatene bød på nye muligheter for lokale jihadistgrupper til å markedsføre seg selv overfor et lokalt og globalt publikum. Ved å kontrollere territorier og poserer som herskere har jihadistopprørere, fra det lille «emiratet» Zinjibar i Jemen i 2012 til Isis-kontrollerte Raqqa og Mosul, forsøkt å vise seg frem som kompetente og dyktige statsadministratorer med et ukorrupt byråkrati og en ordensmakt som sørger for et puritansk og strengt islamsk levesett. Jihadistene er ikke bare opptatt av å vise flid i praktiseringen av ekstreme tolkninger av sharialover eller i bekjempelsen av enhver manifestasjon av polyteisme og vantro. De markedsfører seg også på en lang rekke mer dagligdagse områder, for eksempel ved å håndheve den offentlige orden, dirigere trafikk, slå hardt ned på kriminalitet, opprettholde og tilby offentlige tjenester til tross for krig og nød, og ikke minst ved å demonstrere hvor ukorrupt deres nye «islamske» styresett er. Hverdagen under isis' styre har blitt rikelig beskrevet i en rekke øyenvitneskildringer, og det bør ikke herske tvil om hvor omfattende og graverende menneskerettighetsbruddene under Isis har vært. Oppslutningen om jihadistenes styre kan likevel være større enn mediedekningen gir inntrykk av. I en borgerkrigssone vil enhver organisasjon som kan tilby et minimum av beskyttelse mot regjeringsstyrkene og fiendtlige militsgrupper, og som kan redusere lovløsheten lokalt, oppnå en betinget støtte fra lokalbefolkningen. ${ }^{36}$

Jihadistiske opprørsgrupper er ofte avhengige av eksterne støttenettverk som kanaliserer midler, ressurser og fremmedkrigere til krigssonen. Isis har vært den mest vellykkede grupperingen når det gjelder rekruttering av fremmedkrigere. I kraft av sine blitzkrieg-lignende erobringer av store territorier i Irak i 20I4, og opprettelsen av «kalifatet» samme år, har Isıs kunnet markedsføre seg med tyngde overfor den globale jihadistdiasporaen. Organisasjonen kontrollerer ikke bare det som ses på som «den mest velsignede jihadfronten» der fremgangen har vært størst; IsIs har også kunnet promotere seg som en islamsk utopi, en gudfryktig islamsk stat som representerer oppfyllelsen av etterlengtede apokalyptiske visjoner om utkjempingen av det endelige slaget mellom islam og dets fiender ved Jerusalems porter. Ved å trekke på disse islamske endetidstradisjonene, og i kraft av deres militære dyktighet på slagmarken, har isis lyktes bedre enn noen annen jihadistgruppe i å trollbinde militante islamister verden over. I løpet av bare noen få år har isis klart kunststykket å overbevise flere titusen av unge 
menn og kvinner fra utlandet om nødvendigheten av å stille seg til tjeneste for Isis og underkaste seg dets ideologiske visjon. Det handler om å gjennomføre den «obligatoriske utvandringen ( hijra)» for å «leve i skyggen av kalifatet» og å søke «martyrium på slagmarken» med sine «mujahideen-brødre». ${ }^{37}$ Denne mobiliseringsevnen er desto mer bemerkelsesverdig $\mathrm{i}$ lys av den høye dødsraten blant utenlandske frivillige som ofte brukes som kanonføde og selvmordsbombere.

\section{UNDERLIGGENDE ÅRSAKER}

Debatten om jihadistbevegelsens ekspansjon i den arabiske verden etter $201 \mathrm{I}$ har kretset rundt en rekke ulike faktorer. En gjennomgang av disse debattene er utenfor rammen av denne studien, og her skisseres bare noen av de vanligste forklaringene. Det amerikanske militærets tilbaketrekning fra Irak rett før den arabiske våren, og Iraks statsminister Nouri al-Malikis marginalisering og diskriminering av den sunniarabiske minoriteten i Irak, blir ofte sett på som to av de viktigste faktorene som muliggjorde et comeback for jihadistbevegelsen i Irak (etter dens knusende militære nederlag mot amerikanerne på slutten av 2000-årene). I tillegg skapte utbruddet av borgerkrigen i Syria på samme tid unike ekspansjonsmuligheter over grensen og inn i nabolandet. Eskaleringen av opprøret i Syria gjorde at det syriske regimet valgte å konsentrere styrkene sine i det sørlige og vestlige Syria; deler av det nordøstlige Syria ble oppgitt. Dermed banet borgerkrigen vei for etableringen av et syrisk tilholdssted for det som da var en hovedsakelig irakisk-dominert jihadistbevegelse.

\section{KOLLAPSEN AV ARABISKE STATER}

Svekkelsen av statlige myndigheters kontroll og autoritet i kjølvannet av folkerevolusjonene preget store deler av Midtøsten og Nord-Afrika, ikke bare Syria. I Maghreb-regionen førte sammenbruddet av Qaddafis regime i Libya til plyndring av store våpenlagre som regimet hadde bygget opp over flere tiår. Resultatet av denne massive «privatiseringen» av konvensjonelle våpen fra Libya var merkbart i hele regionen. Et av de mest synlige resultatene var et dramatisk oppsving $i$ jihadistisk opprørsvirksomhet og terroraksjoner. Kapringen av In Amenas-anlegget i Algerie, da en jihadistgruppe tok kontrollen over et godt beskyttet gassfelt, og erobringen av store deler av Nord-Mali i 20I2, ville knapt nok vært tenkelig uten den våpentilførselen og det handlingsrommet som Libya-krisen hadde skapt.

På samme måte som i Syria oppgav også jemenittiske regjeringsstyrker kontrollen over betydelige deler av landet som følge av folkeopprørene, spesielt i det sørlige Jemen, der AQAP og dets lokale støttespillere grep muligheten til å befeste seg som en territoriell aktør. Borgerkrigen i Jemen, der den avsatte diktatoren Ali Abdullah Saleh gikk sammen med Houthi-opprørerne mot det nye saudi-støttede regimet, skapte en situasjon der jihadistopprørere unngikk å velge side. I stedet fokuserte jihadistene på å konsolidere sine baseområder i sør og vinne folkelig støtte og legitimitet lokalt gjennom allianser med stammegrupper og lokale sivile eliter. Også i Libya førte statssammenbruddet til en kompleks borgerkrig der de to dominerende aktørene, Verdighetsalliansen, ledet av general Heftar, og Daggrykoalisjonen, basert i Tripoli og Misrata, brukte langt mer energi på å bekjempe hverandre enn på å konfrontere den nye trusselen fra militante islamistgrupper, herunder Isis-grupper i Benghazi, Derna og Sirte. I Syria rettet Asad-regimet mer eller mindre konsekvent sine militære ressurser mot de syriske revolusjonære opposisjonsstyrkene, ikke Isis eller de kurdiske enklavene i nord-øst, ettersom Asad åpenbart vurderte førstnevnte som sin farligste fiende. I de tidlige fasene av den 

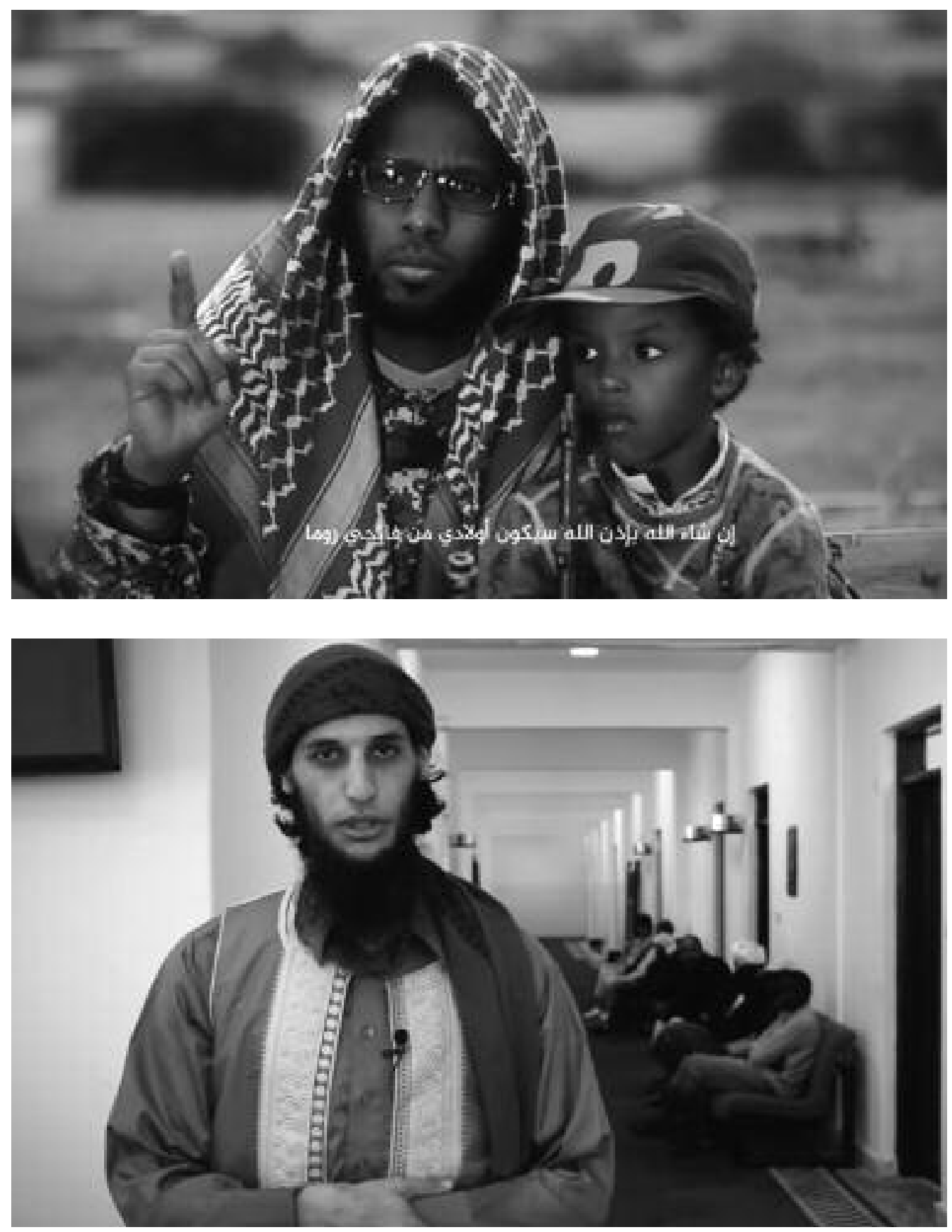

Figur 8.1: Skjermdump fra videoer produsert av ISIS Libya i 2016. 
syriske borgerkrigen ble dermed den jihadistiske ekspansjonen i Syria muliggjort av det som så ut som en de facto allianse mellom Asad og isis.

\section{TVETYDIGHET OM USAS ROLLE I MIDTØSTEN}

En annen viktig faktor bak jihadistbevegelsens vekst etter 20II var den nye tvetydigheten rundt usAs rolle i Midtøsten under president Barack Obama. Særlig i Gulf-monarkiene tok den herskende eliten notis av hvordan usa hadde tillatt, og nærmest applaudert, Hosni Mubaraks fall. Den aldrende presidenten hadde vært en av UsAs mest trofaste allierte $\mathrm{i}$ regionen i flere tiår og hadde vært mottaker av amerikansk militær bistand i milliardklassen siden I970-årene. Under president Obama hadde usa latt Muslimsbrødrene komme til makten i Kairo, et av maktsentraene i den arabiske verden. Atomavtalen med Iran styrket ytterligere denne mistanken om at USA ikke lenger ville stå brast og bram med sine arabiske allierte i Gulfen. usAs Midtøstenpolitikk hadde tradisjonelt vært sentrert rundt tre målsetninger: hegne om Israels sikkerhet, sikre full tilgang til regionens oljeressurser og bekjempe internasjonal terrorisme. ${ }^{38} \mathrm{I}$ kjølvannet av de arabiske folkeopprørene og USAs reaksjon så man en reorientering av arabisk utenrikspolitikk. Siden man ikke lenger kunne stole på usA for å demme opp for Irans stormaktsambisjoner, beveget man seg i retning av en mer foroverlent utenrikspolitikk, ledet an av Saudi-Arabia og De forente arabiske emirater (FAE). ${ }^{39}$ To politiske agendaer var dominerende: (I) eliminering av politisk islamisme generelt og Muslimbrødrene spesielt som en legitim politisk aktør i regionen, og (II) mobilisering av arabisk opinion for å gjenetablere sunni-arabisk hegemoni vis-à-vis den iranske sjiamuslimske trussel.

Dette nye spillet besto med andre ord av en kombinasjon av kontrarevolusjon og sekterisk mobilisering. Bekjempelse av jihadistgrupper var ikke lenger en hovedprioritet til tross for tallrike offisielle uttalelser om nødvendigheten av å føre krig mot isis og al-Qaida. Kampanjen mot Muslimbrødrene (мв) var i høyeste grad kontraproduktiv. Saudi-Arabia og FAE forbød мв i regionen og ga sjenerøs finansiell bistand til den nye militærjuntaen i Egypt. På denne måten bidro det saudiarabiske kongedømmet og dets allierte til å marginalisere det mest potente politiske islamistiske alternativet til jihadistbevegelsen, og de har vært sentrale i å befeste det hittil mest undertrykkende regimet i egyptisk moderne historie. Resultatet er forutsigbart. ${ }^{40}$ Nær sagt alle politiske kanaler er stengt, tusenvis av мв-demonstranter er blitt drept og titusenvis av politiske fanger sitter fremdeles fengslet. Samtidig opplever egyptiske jihadistgrupper en tilstrømning av avhoppere fra moderate islamistgrupper. ${ }^{41}$ Egypt under Sisis diktatur står overfor det mest alvorlige jihadistopprøret i Egypt etter uavhengigheten, et opprør der voldsnivået langt overgår det man hadde under lavintensitetskonflikten i I990-årene. ${ }^{42}$

\section{EN TRANSNASJONAL OPPRØRSBEVEGELSE}

En annen og kanskje mer grunnleggende årsak til jihadistbevegelsens økte ekspansjonsevne i regionen ligger i dets transnasjonale karakter. I motsetning til etnonasjonalistiske bevegelser og lokale sosiorevolusjonære grupper er ikke jihadister ideologisk bundet til å kjempe kun i ett land eller mot ett bestemt nasjonalt regime. Al-Qaidas væpnede kamp (deres "globale jihad») er en panislamistisk revolusjonær kamp for «frigjøring» av alle «islamske områder», og retter seg mot det jihadistene kaller en koalisjon av «korsfarere» (vestlige land) og «tyranniske frafalne regimer» (for eksempel muslimske stater som har alliert seg med usA). Hele verden er dermed ideologisk sett en legitim arena for jihadistbevegelsens «militære» operasjoner, selv om størstedelen av opprørskampen har blitt ført av geriljagrupper i spesifikke 
2008 (Mai til september)

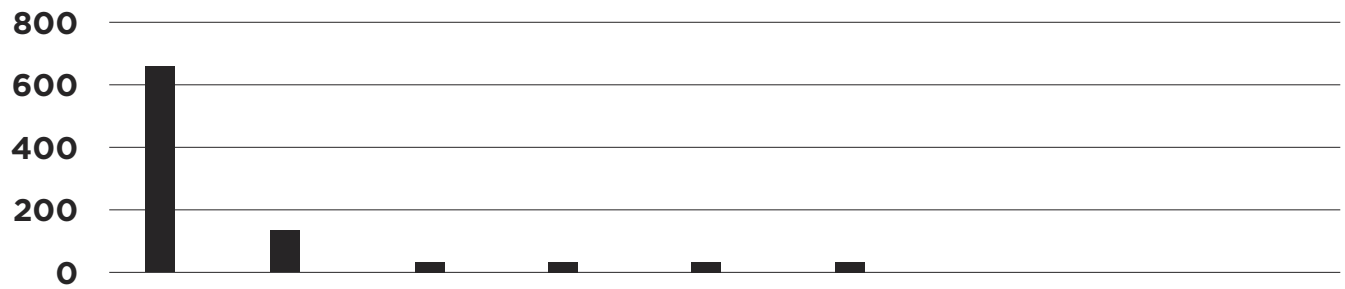

Irak Afghanistan Somalia Maghreb Tsjetsjenia Palestina

2008 (Februar til desember)

1500

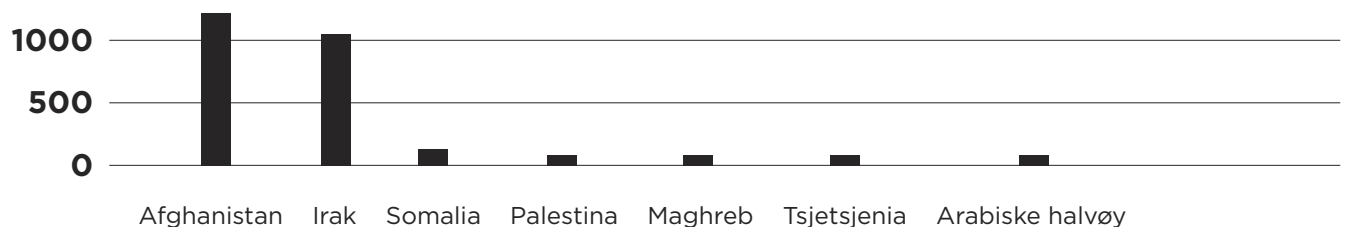

Afghanistan Irak Somalia Palestina Maghreb Tsjetsjenia Arabiske halvøy

\section{9}

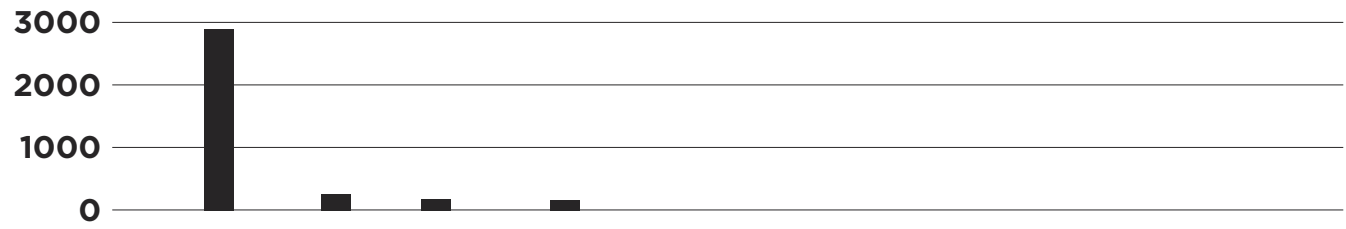

Afghanistan Irak Somalia Maghreb

2010

5000

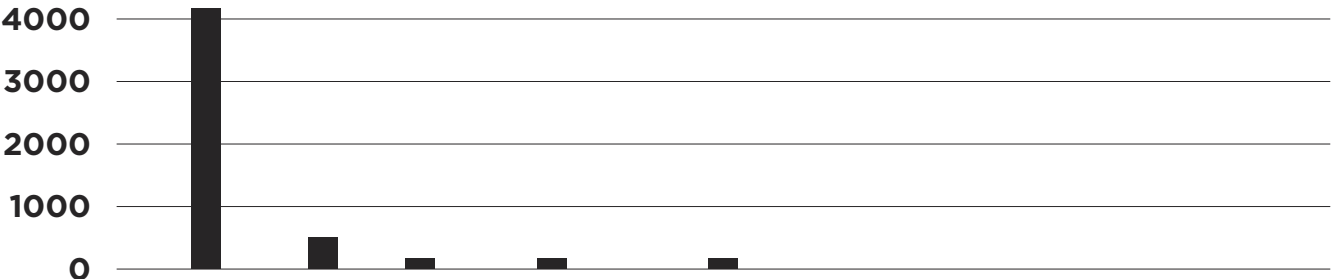

Afghanistan Irak Somalia Maghreb Arabiske halvøy

Figur 7.1: Årlig antall kommunikéer publisert på det arabiskspråklige jihadistforumet Falluja mellom 2007 og 2013, sortert etter den primære landtilknytningen til gruppen som signerer/utsteder det enkelte kommuniké. 
konfliktsoner, ikke av internasjonale terroristceller. I løpet av de siste 25 årene har militante islamistgrupper utkjempet opprørskriger fra Asia og Kaukasus til Midtøsten, Nord-Afrika, Sahelregionen og Øst-Afrika. De siste årene har alQaida og IsIs i stor grad samlet mange av disse lokale islamistopprørerne under sine respektive faner. Denne felles ideologiske transnasjonale agendaen skaper en seighet og motstandsdyktighet som lokalt orienterte grupper mangler. Nederlag i et område oppveies av fremgang på andre «jihadfronter». Enkeltområder kan tapes og oppgis, men krigen fortsetter. Det som for en etnonasjonalistisk opprørsgruppe ville ha vært et knusende militært nederlag, er bare et begrenset taktisk tilbakeslag for jihadistene. Denne mangelen på kritiske territorielle tyngdepunkter øker sjansene for overlevelse og kan forklare hvorfor jihadistbevegelsen, tross gjentatte militære nederlag, stadig kommer tilbake med fornyet styrke og med nye lokale partnerorganisasjoner.

Riktig nok har mange av opprørsgruppene som faller inn under merkelappen jihadisme en sterk lokal forankring og er ofte bemannet nesten utelukkende av lokale rekrutter, og den lokale karakteren til opprørerne som hevdes å være global jihadister bør ikke undervurderes. ${ }^{43}$ Likevel samhandler jihadistopprørerne med et stort nettverk av likesinnede grupper under al-Qaidas (eller IsIs') overordnete lederskap, og de understøttes av geografisk spredte nettverk av dedikerte støttespillere og sympatisører. Denne globale jihadistdiasporaen har i løpet av de siste tiårene vokst seg stadig sterkere. Dette manifesterer seg tydeligst $\mathrm{i}$ evnen til å mobilisere finansielle ressurser, beherske internettbaserte propagandakanaler, rekruttere fremmedkrigere og tilrettelegge for transport og forsyninger til opprørskontrollerte områder. Den astronomiske økningen $i$ antall fremmedkrigere til Is Is' slagmarker i Syria og Irak i løpet av de siste årene er kanskje det tydeligste eksempel på dette. Titusenvis av frivillige har blitt rekruttert fra flere titalls land over hele verden og fremmedkrigerstrømmen er en tankevekker når det gjelder jihadistbevegelsens evne til militær mobilisering. I korthet kan det argumenteres for at jihadistbevegelsens styrke ligger i denne unike kombinasjonen av sterk lokal forankring og integrasjon med effektive transnasjonale nettverk. Sistnevnte muliggjør avtapping fra en bred global ressursbank. Det gir jihadistbevegelsen en unik evne til raskt å vokse seg sterke i nye områder der statsstrukturene er svake. På samme måte har bevegelsen, når forholdene lokalt forverres, kapasitet til hurtig forflytning til nye frontavsnitt.

Jihadistbevegelsens motstandsdyktighet er også et resultat av den menneskelige kapitalen den har ervervet seg ved deltakelse i en lang rekke konfliktområder. Ledersjiktet i al-Qaida og dets ulike regionale avdelinger består av veteraner med årelang erfaring fra mange ulike krigssoner, ofte helt tilbake til den afghanske frigjøringskrigen på I980-årene. Denne akkumulerte geriljakompetansen deles mellom jihadistgruppene. Den dokumenteres og formidles via det store og voksende onlinebiblioteket av jihadistmemoarer, militærmanualer, lydopptak fra forelesninger og videomateriale. I tillegg har antakelig selve praktiseringen av geriljakrig i ulike konfliktsoner over en såpass lang periode fungert som en slags darwinistisk utvelgelsesprosess der bare de dyktigste kampveteranene overlever.

Den irakiske fronten er et illustrerende eksempel. Etter å ha fått sitt første store fotfeste i regionen i tiden etter invasjonen av Irak i 2003, sto jihadistopprørerne overfor en formidabel militær motstander på slagmarken. Ved å utkjempe en langvarig borgerkrig mot amerikanske styrker og dets irakiske allierte, led al-Qaida i Irak, forløperen til isis, enorme tap på slutten av 2000-årene. Imidlertid overlevde organisasjonen. 
400

300

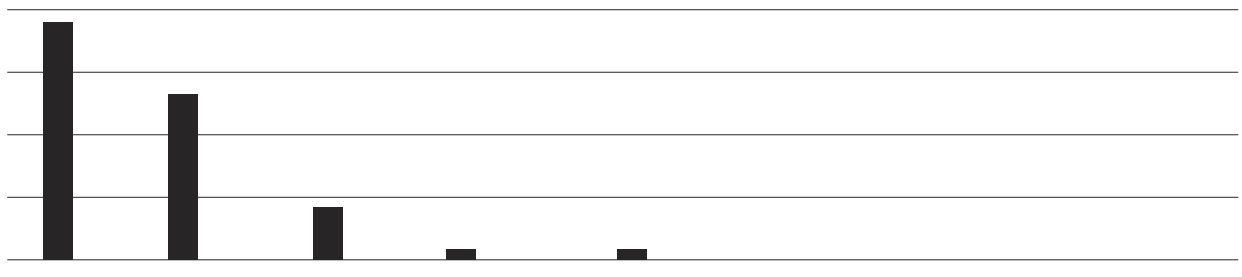

0

Irak Afghanistan Somalia Maghreb Arabiske halvøy

\section{2}

500

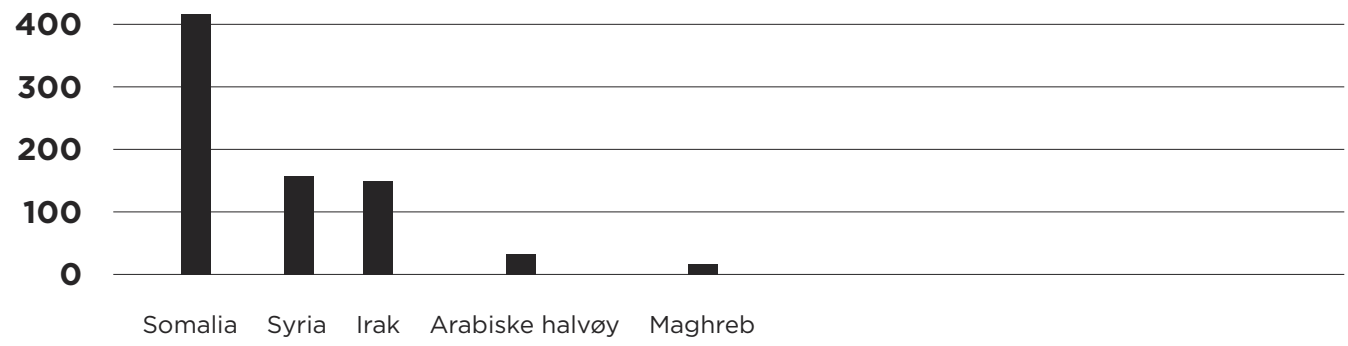

2013 (Januar til april)

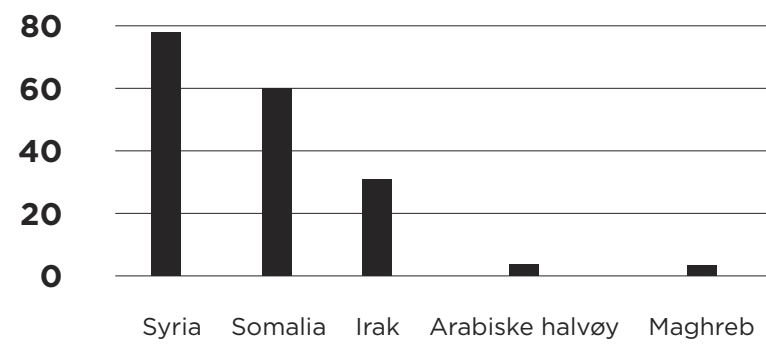

Figur 7.2: Årlig antall kommunikéer publisert på det arabiskspråklige jihadistforumet Falluja mellom 2007 og 2013, sortert etter den primære landtilknytningen til gruppen som signerer/utsteder det enkelte kommuniké. 
Den ledes av en kjerne erfarne irakiske jihadister, og disse maktet å reorganisere restene av bevegelsen til en effektiv kamporganisasjon da USA trappet ned sitt militære nærvær. Under det nye IsIs-flagget beviste organisasjonen sin dyktighet gjennom en serie oppsiktsvekkende militære seire på slagmarken i 20I3-20I4, og etableringen av «kalifatet», med hovedsete i Mosul og Raqqa, var et faktum.

\section{JIHADISTISK KRIGSRAPPORTERING FORTELLER}

En måte å synliggjøre den transnasjonale ideologiske karakteren til dagens jihadistbevegelse er å studere deres krigsrapportering. Et godt sted å begynne er jihadistiske webfora. (Se eksempel i figur 6.) Disse forble den primære virtuelle arena, møteplass og kommunikasjons-/propagandakanal for jihadistbevegelsen fra tidlig på 2000-årene og frem til sosiale medier, og særlig Twitter, overtok deres dominerende posisjon i $20 \mathrm{I} 2-2013 .{ }^{44}$ Jihadistforaene har vært en meget viktig kilde til forståelsen av bevegelsen. Her kan man utforske jihadistbevegelsens forestillingsverden, dets ideologiske betraktninger og ikke minst deres prioriteringer i militære og politiske saker. Man kan identifisere hvilke grupper som betraktes som legitime utøvere av «jihad», og man kan måle hvor mye som rapporteres, fra hvilke frontavsnitt, i hvilke tidsperioder. Det siste er viktig som indikator på graden av reell internalisering av idéen om en global jihad. Dersom bare én «jihadfront» omtales og fremmes gjennom lange perioder er dét et tegn på at pan-islamske «global jihad»-engasjementet er fraværende, og at evnen til å skifte fokus mot nye frontavsnitt er svak.

Ved å gjennomføre en analyse av kommunikéene som er lagt ut på ledende jihadistwebfora mellom 2005 og 2013, kan man se et mønster som har påfallende likheter med mange globale solidaritetsbevegelser: Aktivistenes kampfokus endrer seg over tid, fra én region til en annen, og fremgang på nye kampfronter gis oppmerksomhet i stedet for å dvele ved tilbakeslag på andre fronter.

I figur 7 er det årlige antall kommunikéer som er blitt lagt ut på det arabiskspråklige jihadistwebforumet Falluja, oppført og sortert med hensyn til den primære geografiske tilhørigheten til gruppene som har signert kommunikéene. Som det fremgår av tabellene har Afghanistan og Irak vekselsvis vært landene med høyest rapportert aktivitet frem til 2orI, med Somalia som den tredje mest omtalte jihadfronten. Alle disse tre landene har opplevd langvarige perioder med full militær okkupasjon, enten av en amerikanskledet koalisjon eller av styrker som har vært nært alliert med usa. ${ }^{45}$ Den jihadistiske krigsrapporteringens fokus på opprørsvirksomhet i muslimske områder under okkupasjon understreker igjen hvor høyt temaet «motstand mot fremmed styre» ruver $\mathrm{i}$ jihadistbevegelsens ideologi.

Rapporter fra andre konfliktområder der jihadistiske opprørsgrupper er aktive, utgjør bare en liten brøkdel av antallet kommunikéer fra Irak, Afghanistan og Somalia. Jihadistisk krigsrapportering fra Maghreb, Tsjetsjenia og Den arabiske halvøy er imidlertid fullt ut til stede gjennom hele perioden, og det forsterker bildet av et globalt opprør med mange aktive fronter. Vekslingen mellom de tre mest dominerende krigssonene kommer også tydelig fram. Den mest aktive fronten har skiftet fra Irak i $2005^{-2007} \mathrm{og}$ 20II til Afghanistan i 2008-2010, videre til Somalia i 20I2, og til slutt til Syria i 20I3. Dette understreker igjen den dynamiske naturen til denne transnasjonale opprørskampanjen. Man kan kanskje ane en viss arabisk etnosentrisitet mot slutten av perioden da krigsrapporteringen fra Taliban-opprøret i Afghanistan gradvis forsvinner, selv om opprøret i Afghanistan pågår med full styrke. ${ }^{46}$ I stedet blir statistikken stadig mer dominert av krigsrapportering fra Syria. Den 

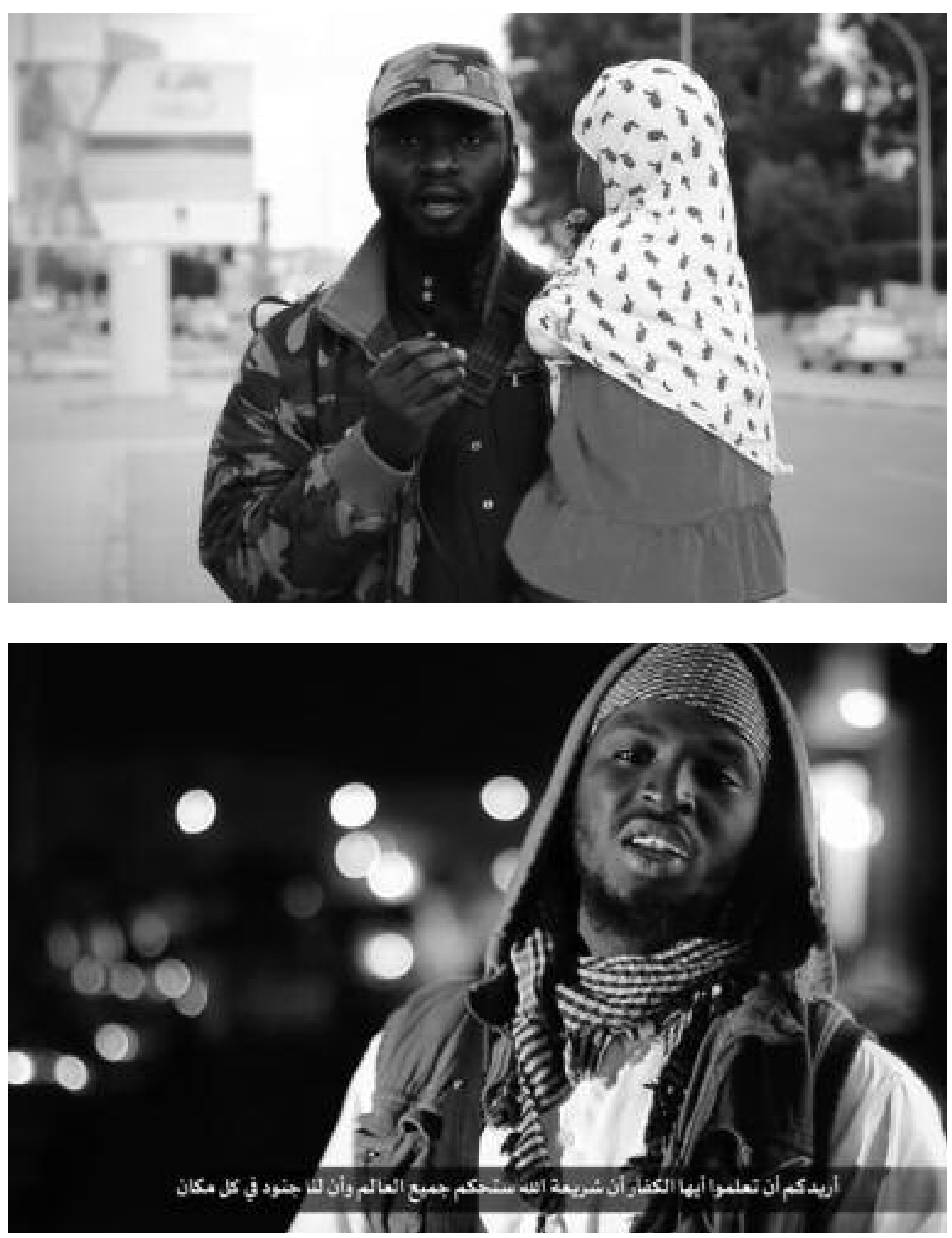

Figur 8.2: Skjermdump fra videoer produsert av ISIS Libya i 2016. 
fortsatte publiseringen av et stort antall kommunikéer fra Somalia i 2012 og 2013 viser imidlertid at de jihadistiske webforaene fortsatt viet mye interesse til Shabaab, al-Qaidas nye gren på Afrikas Horn, selv under de dramatiske hendelsene som fant sted i løpet av den arabiske våren.

\section{MOT EN STORKOALISJON?}

En annen god indikator på eksistensen av en utpreget transnasjonal jihadistbevegelse er den tidligere nevnte fusjoneringsprosessen, hvor lokale opprørsgrupper har sluttet seg til al-Qaida-nettverket fra tidlig på 2000-årene og frem til i dag. Det finnes riktignok flere eksempler på rivalisering mellom jihadistene der utbrytergrupper og splittelser har svekket bestrebelsene mot å danne en felles front. Det er imidlertid en feilslutning å hevde at nærværet av intern rivalisering reduserer jihadistbevegelsen til et tomt skall og at det dermed er meningsløst å snakke om en jihadistbevegelse. ${ }^{47}$ Det er talløse eksempler på samarbeid og fusjoner i jihadismens nyere historie: den egyptiske gruppen Islamsk Jihad fusjonerte med al-Qaida i 20or; Monoteisme og jihad (Zarqawis gruppe) ble fullverdig medlem av al-Qaida i 2004; Algeries GSPC sluttet seg til alQaida-nettverket i 2007; jemenittiske og saudiarabiske jihadistgrupper sluttet seg sammen til AQAP i 2009; somaliske Shabaab absorberte flere lokale grupper og trådte formelt inn i al-Qaida i 20I2; og Nusra-fronten, en av de sterkeste opprørsgruppene i Syria, har vært assosiert med alQaida-nettverket omtrent siden dens etablering. ${ }^{48}$ En lignende serie av absorberinger av lokale jihadistgrupper har foregått under Is Is-paraplyen i tiden etter 20II. Den viktige Ansar al-Islam-organisasjonen, en av de mest dødelige opprørsgruppene i Irak i 2000-årene, ble en del av Isis rundt 20I4. Samme år ble også den Egypt-baserte gruppen Ansar Bayt al-Maqdis utnevnt til en IsIs-gren under navnet Sinai-provinsen. Det er kommet tallrike løfter om troskap til kalif Ibrahim, Isıs' ubestridte leder, både fra mindre opprørsgrupper og fra store regionale geriljagrupper som Boko Haram i det nordlige Nigeria og Uzbekistans islamske bevegelse (IMU), sistnevnte med hovedsete i de urolige grenseområdene mellom Afghanistan og Pakistan.

Mye har blitt skrevet om rivaliseringen mellom al-Qaida og isis, der ekspertvurderingene har predikert overoptimistiske scenarier om jihadismens forestående undergang, forårsaket av intrajihadistisk borgerkrig. Andre mer pessimistiske analyser har fremstilt rivaliseringen som et tegn på jihadistbevegelsens nyvunne vitalitet, der kappestrid om hegemoni og nye tilhengerskarer motiverer de to rivalene til stadig å forbedre sine dødelige taktikker $\mathrm{i}$ internasjonal terrorisme. ${ }^{49} \mathrm{Ut}$ fra jihadistenes egne rapporteringer er det lite som tyder på at Is Is har evnet å slå dype sprekker i alQaidas koalisjon. De viktigste regionale avdelingene har ikke hoppet av til Is Is, og al-Qaida har til og med klart å danne to nye og viktige regionale grener siden 20Ir: Nusra-fronten og AlQaida på Det indiske subkontinentet (AQIs). Det er bare grupper med løs tilknytning til al-Qaida som har sluttet seg til isis, ${ }^{50}$ samt mange av de mindre nyankomne jihadistgruppene fra perioden etter 20Ir. Den afghanske Taliban-geriljaen, en av al-Qaidas viktigste allierte siden I990-årene, ${ }^{51}$ har heller ikke sluttet seg til «kalifatet», men har i stedet valgt å gå til full krig mot isis-tilhengere $i$ Afghanistan for å rydde en mulig fremtidig rival av veien. Mens isis gjør mye ut av «kalifatet», protostaten i Syria og Irak, er det verdt å huske på at al-Qaida, via sine mange regionale avdelinger, også opprettet og administrerte territorielle «emirater» i tiden etter 2orI, blant annet i Jemen og Nord-Mali. Den utbredte oppfatningen av at al-Qaida er uinteressert i territoriell konsolidering og statsbygging er både misvisende og unøyaktig. ${ }^{52}$ Det er verdt å merke seg at Isis bare har 
klart å danne én ny territorial protostat utenfor «kalifatet» i Syria og Irak, og denne har vært begrenset til by-enklaver i Libya med mye mindre befolknings- og inntektsgrunnlag enn moderorganisasjonen. ${ }^{53}$

\section{VÅR TIDS HEGEMONISKE OPPRøRSIDEOLOGI}

En nært forestående kollaps av jihadismen som opprørsideologi eller al-Qaida som organisasjon var mantraet i 2011 da de arabiske folkerevolusjonene i Midtøsten trollbandt en hel verden. I dag fremstår slike spådommer som både ubegrunnete og naive. Den pågående ISIS-AQrivaliseringen betyr ikke at jihadistbevegelsen er betydelig svekket, men snarere at jihadisme som ideologi har styrket sin posisjon som kanskje den mest attraktive og populære ideologien og operative rammen for væpnet opprør i Midtøsten i dag. Jihadismens hegemoniposisjonen som væpnet opprørsideologi gjelder antakelig også mange muslimske majoritetsland utenfor Midtøsten. Aldri før har så mange lokale opprørsgrupper og militante fraksjoner i den islamske verden festet på seg jihadistlogoen og søkt drahjelp fra merkenavnene al-Qaida og Isis. Hvorfor dette skjer har ikke bare med ideologisk appell og publisitetssøken å gjøre. For mange lokale opprørsgrupper handler det om kampen om ekstern støtte og om å vinne fordeler vis-à-vis lokale konkurrenter i kampen om tilgang til ressursene til den globale jihadistdiasporaen. $.^{54} \mathrm{Ut}-$ viklingen ligner til en viss grad på populariteten til marxismen og maoismen blant opprørsgrupper i den tredje verden på 1960- og 1970-årene. Den store forskjellen er imidlertid at marxistiske opprørere kunne regne med materiell og ideologisk støtte fra en lang rekke kommunistiske stater. Det kan ikke jihadistbevegelsen. I stedet må de stole på private donorer og transnasjonale støttenettverk, og bare unntaksvis vil de kunne oppnå reell støtte fra stater. Private sponsorer for jihadist- grupper har imidlertid blitt langt flere og mer effektive på grunn av den kombinerte effekten av internettkommunikasjon, global migrasjon og fremveksten av store muslimske diasporasamfunn i høyinntektsland. ${ }^{55}$

\section{UNGDOMMENS ANKOMST}

Den moderne jihadismen har vist seg å ha betydelig appell $i$ den arabiske verden, spesielt blant de unge, til tross for jihadistbevegelsens bruk av stadig mer brutale voldsmetoder. ${ }^{56}$ Jihadistrekrutter kommer ikke bare fra de fattige og marginaliserte delene av befolkningen, men vel så gjerne fra den utdannede middelklassen. Europeiske fremmedkrigerne synes å komme fra lavere sosioøkonomiske samfunnslag; overraskende mange har vært straffedømt for kriminalitet før de gjennomgikk en religiøs omvendelse. Eksisterende litteratur om muslimsk radikalisering er svært tvetydig om årsaker, og tilbyr ofte en lang smørbrødliste med forslag til mulige drivkrefter, fra politisk undertrykkelse og en følelse av ydmykelse og utenforskap til materiell fattigdom og mangel på utdanning og muligheter. En uttømmende diskusjon rundt dette er utenfor denne studiens rammer.

Det er imidlertid verdt å merke seg ungdommens rolle i moderne jihadistbevegelser. Dette er et interessant og understudert aspekt ved moderne jihadisme. Jihadistgrupper er svært antipatriarkalske og «anti-tribale» både i ideologi og organisasjonsform. Dette kan virke som et merkelig argument $i$ lys av den velkjente kvinnefiendtlige diskursen og praksisen som mange mannlige jihadister fremviser. Imidlertid kan patriarkat også forstås som dominans av eldre menn over unge menn gjennom slektskapsorganisasjoner og/eller klientellistiske nettverk. Når denne definisjonen anvendes finner man at jihadistopprørere i overraskende grad er antipatriarkalske, noe som skiller dem klart fra 
hvordan autoritet utøves i Midtøsten i dag. ${ }^{57}$ Jihadistene ikke bare snakker om, men de praktiserer også en antipatriarkalisme ved å la unge personer, hovedsakelig unge menn, besette maktposisjoner og utøve myndighet i områder der jihadistene styrer. Dette fremgår tydelig $\mathrm{i}$ jihadistiske propagandavideoer som er kommet fra Isisog al-Qaida-styrte protostater, områder hvor jihadistene er i stand til å utøve sin ideologi i praksis. Som man kan se av figur 8 , er ledende byråkrater og talspersoner i disse områdene unge menn i begynnelsen av tyveårene. Dette ungdommelige uttrykket er desto mer oppsiktsvekkende i en region der lederstillinger i politikk og næringsliv vanligvis er forbeholdt gamle menn.

\section{AVSLUTTENDE KOMMENTARER}

Denne studien har diskutert årsakene bak jihadistbevegelsens oppsiktsvekkende regionale ekspansjon siden 200I, spesielt i tiden etter den arabiske våren. Som det fremgår av ovenstående drøfting har denne ekspansjonen flere forklaringer. Én av grunnene er at jihadistene nyter en viss grad av folkelig støtte i mange land i Midtøsten, noe som muliggjør et langt friere spillerom enn det som ville ha vært tilfelle dersom jihadistene bare besto av små isolerte terroristceller. Videre har drøftingen vist at dagens jihadistgrupper er særdeles motstandsdyktig mot militær represjon fordi den i så høy grad er del av en transnasjonal bevegelse uten sårbare territorielle tyngdepunkter. Samtidig har jihadistbevegelsen, gjennom sine mange lokale forgreninger, en sosial forankring som skaper lokal legitimitet. I møte med overlegen militærmakt gjør jihadistbevegelsen som alle andre geriljagrupper: De trekker seg ut for å omgruppere med fornyet styrke på et frontavsnitt der vilkårene for suksess er bedre. Men til forskjell fra lokale geriljagrupper har jihadistbevegelsen hele den islamske verden som tumleplass.
Den utbredte konseptualiseringen av jihadistbevegelsen som et internasjonalt terrornettverk uten folkelig støtte står i skarp motsetning til dagens virkelighet, og er en farlig misforståelse. I stedet representerer bevegelsen et bredt anlagt og globalt opprør med territorielle protostater, pluss betydelig folkelig støtte både lokalt og fra en stor jihadistdiaspora. ${ }^{59}$ Dette forklarer bevegelsens betydelige evne til å mobilisere fremmedkrigere og ressurser til nye konfliktområder. Bevegelsen kan ikke beseires med militærmakt. Tvert imot har tiden etter iI. september-angrepene og den usA-ledede krigen mot terror vist at utstrakt bruk av militærmakt, intervensjoner og langvarige okkupasjonsregimer virker mot sin hensikt. Først når jihadistbevegelsen blir bedre konseptualisert kan man utvikle en strategi for å begrense dens videre ekspansjon. Dette fordrer imidlertid en vilje til å akseptere at jihadismen representerer et politisk opprør som er et resultat av reell politisk misnøye.

\section{$\cdot f \cdot$}

BRYNJAR LIA er professor i Midtøsten-studier ved Universitetet i Oslo.

1 Jeg vil takke Dag H Tuastad, Joakim Parslow, Erling Lorentzen Sogge, Tore Nyhamar, Petter Nesser, Thomas Hegghammer, Jon Nordenson og to anonyme fagfeller for konstruktive kommentarer og tilbakemeldinger på tidligere utkast av denne artikkelen.

2 Amerikanske myndigheter anvender ikke lenger begrepet offisielt. Obama-administrasjonen nedtonet bruken av GWOT-begrepet, og i 2013 uttalte Obama at "the global war on terror" var over, og at fokuset nå skulle rettes mot spesifikke nettverk: "We must define our effort not as a boundless 'Global War on Terror,' but rather as a series of persistent, targeted efforts to dismantle specific networks of violent extremists that threaten America”. Sitert i "Obama: 'Global War on Terror' Is Over”, US News \& World Report 23. mai 2013. Hentet fra: usnews.com/news/articles/2013/05/ 23/obama-global-war-on-terror-is-over

3 Jihadistbevegelsen forstås her som al-Qaida og dets lokale og regionale avdelinger, utbrytergrupper (i første rekke ISIS), tilknyttede organisasjoner og sympatisører. Bevegelsen består av flere nivåer: (i) et historisk lederskap, al-Qaida, som i de senere årene er blitt utfordret av et nytt organisasjonssentrum 
ved fremveksten av ISIS; (ii) et bredt nettverk av organiserte sunnimuslimske opprørs- og terrorgrupper fra Sørøst-Asia til Marokko, hvorav noen er formelt sett "avdelinger" eller "provinser" $\mathrm{i}$ henholdsvis al-Qaida eller ISIS; og til sist (iii) en jihadistdiaspora, en bred tilhengerskare av sympatisører og støttespiller i svært mange land, der miljøer som Profetens Ummah og Sharia4Belgium inngår. For en historisk oversikt over bevegelsens utvikling, se Brynjar Lia, "Jihadbevegelsen i den arabiske verdenen før og etter 2011”, Babylon: Nordisk tidsskrift for midtøstenstudier 12, no. 2 (2014): 8-22.

4 Jihadisme, eller global jihadisme, defineres her som al-Qaidas ideologi. Mens islamisme gjerne forstås som en politisk ideologi, fremmet av organiserte bevegelser med det formål å innføre islamsk lovgiving og etablere islamske stater, kan jihadisme gjerne beskrives som en ytterliggående voldelig avart av islamismen. Det finnes flere varianter av jihadisme der lokal og regional kontekst og "fiendehierarkiet" (dvs. en rangering av hvilke fiender som betraktes som farligste på kort sikt) varierer fra gruppe til gruppe. ISIS er som kjent en utbrytergruppe fra al-Qaida-nettverket, men deler de aller fleste hovedtrekkene ved al-Qaidas ideologi. Et av de mest sentrale trekkene ved jihadisme som ideologi er idéen om at hele den islamske verden er okkupert, direkte eller indirekte, av en global allianse av kristne "korsfarerstater" (først og fremst USA, dernest dets vestlige allierte og andre "vantro" stormakter) og muslimske "frafalne" og "forræderske" regimer der sistnevnte agerer som lakeier for førstnevnte. På dette grunnlaget trekkes konklusjonen om at militær og voldelig kamp, omtalt som jihad, er det eneste legitime og virkningsfulle handlingsalternativet og at det videre påligger alle troende muslimer en individuell plikt å delta i denne kampen, fortrinnsvis med våpen $\mathrm{i}$ hånd. Siden fiendene ikke er geografisk begrenset til ett territorium, må kampen føres uavhengig av landegrensene. Dyrkingen av en martyrkultur og bruk av selvmordsaksjonister både i og utenfor konflikt områder er andre typiske kjennetegn. Ideologien avviser etniske og nasjonale skillelinjer til fordel for en felles panislamsk identitet. Jihadisme kan i så henseende gjerne be tegnes som en type ekstrem pan-islamistisk nasjonalisme. Teologisk sett er ideologien inspirert av konservativ salafisme, herav betegnelsen salafi-jihadisme, mens dets militærstrategiske og politisk revolusjonære innhold i stor grad stammer fra egyptiske, palestinske og syriske militante islamister som Sayyid Qutb, Abdallah Azzam og Abu Mus'ab al-Suri. Mange muslimske væpnete grupper inngår ikke i jihadistbevegelse siden de mangler (noen av) de fellestrekkene nevnt ovenfor. De to mest kjente eksemplene er Hamas og Hizbullah som diskvalifiseres fordi de er hovedsakelig nasjonalt orienterte, deltar i demokratiske valg, har et nært forhold til Iran, og/eller er sjiamuslimske. Helt siden 1990 tallet har jihadistbevegelsen hatt en ganske sterk selvforståelse av hvem som er innenfor og hvem som står utenfor nettverket. En illustrasjon på dette var de opphetete debattene i siste halvdel av 1990-tallet om den algeriske GIA-gruppen var en legitim jihadistgruppe eller om Taliban-regimet i Afghanistan var et legitimt "islamsk emirat" og om deres kamp mot Nord-Alliansen var "jihad" der jihadistene burde delta militært. De jihadistiske webforaene som inntil 2013 var den fremste medieplattformen for jihadistbevegelsen, var sentrale i å definere yttergrensene for jihadistbevegelsen ved å velge hvilke grupper som fikk publisere sine militære kommunikéer på webforaene.

5 "How Many People Have Been Killed in ISIS Attacks Around the World", The New York Times 16. juni 2016. Hentet fra nytimes.com/interactive/2016/03/25/world/mapisis-attacks-around-the-world.html

6 For et illustrerende eksempel på den kontraproduktive effekten av den USA-ledede kampen mot jihadistbevegelsen, se f.eks. Hassan Hassan, "Washington's War on the Islamic State Is Only Making It Stronger”, Foreign Policy 16. juni 2016. Hentet fra http://foreignpolicy.com/2016/06/16/ washingtons-war-on-the-islamic-state-is-only-making-itstronger-syria-iraq-libya/

7 Se f.eks. Omar Ashour, The De-Radicalization of Jihadists. Transforming armed Islamist movements. London \& New York: Routledge, 2009 og Hamed El-Said \& Jane Harrigan, Deradicalizing Violent Extremists: Counter-radicalization and deradicalisation programmes and their impact in Muslim majority states. London \& New York: Routledge, 2013.

8 For en diskusjon om motsetningene mellom de typiske "kinetiske" antiterrortiltakene (herunder CIAs droneprogram) og det amerikanske utenriksdepartementets "myke kontraterrortiltak", se Jason Rineheart, "Counterterrorism and Counterinsurgency", Perspectives on Terrorism 4, no. 5 (2010). Hentet fra terrorismanalysts.com/pt/index.php/pot/ article/view/122/html; og “The Role of Diplomacy and Soft Power in Combatting Terrorism", NATO Center of Excellence, Defence against Terrorism (COE-DAT) workshop, Tyrkia, udatert. Hentet fra coedat.nato.int/ publication/workshop_reports/04-Diplomacy_

Soft_Power_Report.pdf. For en studie av variasjonen mellom myke og harde maktmidler i USAs kontraterrorpolitikk, se Layla Saleh, "Soft Power, NGOs, and the US War on Terror". University of Wisconsin-Milwaukee, $\mathrm{PhD}$ Dissertation, 2012. Hentet fra dc.uwm.edu/cgi/viewcontent.cgi?article= 1069\&context=etd

9 Se f.eks. “Top Secret America': A look at the military's Joint Special Operations Command”, Washington Post 2. september 2011. Hentet fra washingtonpost.com/world/ national-security/top-secret-america-a-look-at-the-militarysjoint-special-operations-command/2011/08/30/ gIQAvYuAxJ_story.html

10 Se f.eks. "The Arab War on Terror", Foreign Policy 22. september 2014. Hentet fra foreignpolicy.com/2014/09/22/ the-arab-war-on-terror/ or "The Rise of the Arab "War on Terror' Discourse”, Muftah.com 1. november 2013. Hentet fra muftah.org/the-rise-of-the-arab-war-on-terror-discourse /\#.V64nXPmLRaQ

11 Meningsmålinger i tidsperioden 2003-5 viser at opp mot en majoritet av respondentene uttrykte "høy" eller "noe" tiltro til Osama bin Laden i flere land i Midtøsten. Se "Islamic Extremism: Common Concern for Muslim and Western Publics", Pew Research Center 14. juli 2005. Hentet fra pewglobal.org/2005/07/14/islamic-extremism-commonconcern-for-muslim-and-western-publics/ 
12 I sine berømte utlegninger om geriljakrig skrev Mao Zedong følgende: "Many people think it impossible for guerrillas to exist for long in the enemy's rear. Such a belief reveals lack of comprehension of the relationship that should exist between the people and the troops. The former may be likened to water the latter to the fish who inhabit it. How may it be said that these two cannot exist together? It is only undisciplined troops who make the people their enemies and who, like the fish out of its native element cannot live." Sitert i Mao Zedong, On Guerrilla Warfare, kapittel 6. Hentet fra marxists.org/reference/archive/mao/works/1937/guerrillawarfare/ch06.htm

13 En annen indikator på den relativt brede støtten til jihadistgrupper i regionen er at deres tilretteleggere og rekrutterere kan operere relativt åpent $\mathrm{i}$ land som Jordan, som i utgangspunktet er en av USAs viktigste støttespillere i regionen. Fra Jordan har anslagvis så mange som 2500 fremmedkrigere blitt rekruttert. Se "Jordan Struggles With Islamic Extremism at Home”, Wall Street Journal 14. august 2016. Hentet fra wsj.com/articles/jordan-struggles-with-islamic-extremism-athome- 1471225840

14 Spørsmålsteksten er som følger: "[p]lease tell me if you have a very favorable, somewhat favorable, somewhat unfavorable or very unfavorable opinion of al Qaeda”. Data for Palestina er ikke tilgjengelige for 2010 og 2012 eller for Tunisia i 2010 og 2011. Basert på data publisert i Concerns about Islamic Extremism on the Rise in the Middle East. Pew Research Center, juli 2014, s. 21. Hentet fra pewresearch.org

15 Figuren viser aggregerte data (i prosent) for respondenter som enten svarer "very favourable" eller "somewhat favourable" på spørsmålet "[p]lease tell me if you have a very favorable, somewhat favorable, somewhat unfavorable or very unfavorable opinion of al Qaeda”. Ibid.

16 Tabellen ble publisert i Arab Opinion Index 2015. Doha: Arab Center for Research \& Policy Studies, 2015. Hentet fra dohainstitute.org

17 En grundig fremstilling av denne terrorkampanjen gis i Thomas Hegghammer, Jibadi in Saudi Arabia. Cambridge: Cambridge Univ. Press, 2010.

18 For en detaljert analyse av dannelsen og utviklingen av alQaida i Irak, se Truls Hallberg Tønnessen, "Al-Qaida in Iraq: The Rise, the Fall and the Comeback". Oslo: UiO, PhDavhandling, 2015.

19 Al-Qaida på Den arabiske halvøy (AQAP eller QAP) var en jihadistgruppe basert i Saudi-Arabia, med hovedsakelig saudiarabiske Afghanistan-veteraner. Etter voldskampanjen 2003-6 flyktet flere av de gjenværende medlemmene av nettverket sørover til Jemen. Forkortelsen AQAP brukes i dag fortrinnsvis om denne Jemen-baserte gruppen som offisielt ble dannet i januar 2009.

20 For en god fremstilling av Shabaabs historie, se Stig Jarle Hansen, Al Shabaab in Somalia: The History and Ideology of a Militant Islamist Group, 2005-2012. Columbia: Colombia University Press, 2013.
21 I Maghreb-regionen ble Groupe Salafiste de la Predication et la Combat (GSPC) dannet i 1998, som en utbrytergruppe fra den største jihadistgruppen i Algerie på 1990-tallet, Groupe Islamique Armée (GIA). Sistnevnte hadde mer eller mindre forsvunnet som aktiv opprørsgruppe på begynnelsen av 2000årene.

22 Se f.eks. Brynjar Lia, "The Islamist Uprising in Syria, 197682: The History and Legacy of a Failed Revolt", British Journal of Middle Eastern Studies 43, nr. 4 (2016): 541-559.

23 Se f.eks. Jenkins, J Craig et al., "Seedbeds of insurgency: Structure and dynamics in the Egyptian Islamist insurgency, 1986-99”, Journal of Peace Research 51, nr. 4 (2014): 470486.

24 Se f.eks. Mohammed M. Hafez, "Armed Islamist Movements and Political Violence in Algeria”, The Middle East Journal, 54, nr. 4 (2000): 572-591; og Luis Martinez, The Algerian Civil War 1990-1998. New York: Columbia Univ. Press, 2000 .

25 Fawaz Gerges, "The decline of revolutionary Islam in Algeria and Egypt", Survival 41, nr. 1 (1999): 113-125.

26 Fokuset på politisk reform for å imøtekomme protestbølgen i 2011 var tydeligst i Marokko der kongedømmet for første gang utnevnte en statsminister fra det islamistiske opposisjonspartiet PJD.

27 Se f.eks. data presentert i Ryan Pereira, "Radical Change: The Impact of Islamic State on Tunisia”, Terrorism Monitor 14, nr. 10 (16. mai 2016): 2-5. Hentet fra jamestown.org/uploads /media/Terrorism_Monitor_Volume_XIV_Issue_01.pdf

28 Se f.eks. Mokhtar Awad og Mostafa Hashem, "Egypt's Escalating Islamist Insurgency", Carnegie Middle East Center (21 oktober 2015). Hentet fra carnegie-mec.org/ 2015/10/21/egypt-s-escalating-islamist-insurgency/ijgn

29 Det har vært relativt få terrorhendelser i Jordan, men flere alvorlige ISIS-tilknyttete planlagte aksjoner, se f.eks. "6 Jordanian security forces killed in car bomb attack on Syrian border", CNN.com 21. juni 2016. Hentet fra edition.cnn.com/2016/06/21/middleeast/jordan-car-bombattack/; "Jordan says foils Islamic State plot to attack civilian, military targets”, Reuters 2. mars 2016. Hentet fra reuters.com/article/us-mideast-crisis-jordan-militantsidUSKCNOW40QA og "Jordan disrupts major al-Qaeda terrorist plot”, Washington Post 21. oktober 2012. Hentet fra washingtonpost.com/world/national-security/jordandisrupts-major-al-qaeda-terrorist-plot/2012/10/21/ e26354b4-1ba7-11e2-9cd5-b55c38388962_story.html

30 Dataene er hentet fra Global Terrorism Database (www.start.umd.edu/gtd), den mest anerkjente og omfattende åpne databasen om terrorisme. Søkekriteriene har vært følgende: Alle hendelser kategorisert som tvetydige er ikke tatt med, heller ikke mislykkede eller planlagte angrep. Vi har ikke gjort systematiske forsøk på å skille mellom terroraksjoner fra jihadistiske og ikke-jihadistiske aktører. Når det gjelder voldsaksjoner utenfor konfliktsonene i Syria, Irak, Libya og Jemen, har jihadistgrupper har stått bak de aller 
fleste kjente aksjoner, og de er dessuten blant de mest dominerende opprørsgruppene $i$ arabiske land med aktive opprørsbevegelser. Man kan derfor anta at det statistiske materialet gir et godt bilde på variasjonene $\mathrm{i}$ jihadistisk vold $\mathrm{i}$ den arabiske verden $i$ den nevnte perioden, om enn ikke et nøyaktig bilde av omfanget.

31 Se f.eks. Christine Petré, "Tunisian Salafism: the rise and fall of Ansar al-Sharia”, FRIDE Policy Brief, nr. 209 (oktober 2015). Hentet fra fride.org/descarga/PB209_Tunisian_ Salafism.pdf; og Aaron Zelin, "Meeting Tunisia's Ansar alSharia”, Foreign Policy 8. mars 2013. Hentet fra foreignpolicy.com/2013/03/08/meeting-tunisias-ansar-alsharia/

32 Se f.eks. Omar Ashour, "Lions Tamed? An Inquiry into the Causes of De-Radicalization of Armed Islamist Movements: The Case of the Egyptian Islamic Group", The Middle East Journal 61, nr. 4 (2007): 596-625; Omar Ashour, "Deradicalisation Revisited", Washington Post 18. februar 2015. Hentet fra washingtonpost.com/blogs/monkeycage/wp/2015/02/18/deradicalization-revisited/; og Hamed El-Said \& Jane Harrigan, Deradicalizing Violent Extremists: Counter-radicalization and deradicalisation programmes and their impact in Muslim majority states. London \& New York: Routledge, 2013.

33 Begrepet introduseres og drøftes i Alexander V. Simmons, Socially Embedded Insurgencies. Monterey: Naval Postgraduate School, 2009. Hentet fra dtic.mil/dtic/tr/fulltext/u2/ a514335.pdf

34 Al-Qaidas nåværende leder, Ayman al-Zawahiri, har diskutert og argumentert for dette i sin epistel fra 2001 med tittelen Knights under the Prophet's Banner, kapittel 11. En engelskspråklig oversettelse er tilgjengelig her: azelin.files.wordpress.com/2010/11/6759609-knights-underthe-prophet-banner.pdf

35 Se Brynjar Lia, "Understanding Jihadi Proto-States", Perspectives on Terrorism: Special Issue on the Islamic State 9, nr. 4 (2015): 31-41. Hentet fra terrorismanalysts.com/ pt/index.php/pot/article/view/441/html

36 Det hevdes fra flere hold at den pågående militære kampanjen mot ISIS kan virke kontraproduktivt og vil over tid kunne radikalisere den sunniarabiske befolkningen i Irak og øke sympatien for ISIS. Under gjenerobringen av byer kontrollert av ISIS har den USA-støttede irakiske militærkampanjen medført store sivile tap, herunder regelrette utenomrettslige henrettelser, tortur og massakrer på sivile. Se "Special Report: Massacre reports show U.S. inability to curb Iraq militias", Reuters 23. august 2016. Hentet fra reuters.com/article/us-iraq-massacres-falluja-special-reportidUSKCN10Y1VD

37 "Thousands Enter Syria to Join ISIS Despite Global Efforts", The New York Times, 26. september 2015.

38 I tillegg, under den kalde krigen var et av USAs viktigste mål å holde Sovjetunionen ute fra Midtøsten.

39 Se f.eks. John Hannah, "Saudi Arabia Strikes Back", Foreign
Policy 16. juni 2016. Hentet fra foreignpolicy.com/2016/ 08/16/saudi-arabia-strikes-back-3/

40 Se f.eks. advarslene til Obama-administrasjonen i denne Brookings Policy-briefen: Tamara Cofman Wittes \& Daniel L Byman, "Muslim Brotherhood Radicalizes", Brookings.edu 23. januar 2014. Hentet fra brookings.edu/research/muslimbrotherhood-radicalizes/

41 Rekruttene har ofte vært tidligere revolusjonære salafister (Hazemun-bevegelsen), misfornøyde MB-ungdommer og andre grupper. Se f.eks. "What's next for Egypt's IS affiliate after killing of leader?”, Al-Monitor 14. august 2016. Hentet fra al-monitor.com/pulse/originals/2016/08/egypt-killingleader-isis-affiliate-ansar-bayt-maqdis.html; og "Push for Retribution in Egypt Frays Muslim Brotherhood”, The New York Times 5. august 2015.

42 Se f.eks. "Egypt's Rising Security Threat", The Tahrir Institute for Middle East Policy, 2015. Hentet fra timep.org/ wp-content/uploads/2015/11/Tahrir_Report_FINAL_ WEB.pdf og Omar Ashour, "Sinai's Stubborn Insurgency: Why Egypt Can't Win”, Foreign Affairs 8. november 2015 Hentet fra foreignaffairs.com/articles/egypt/2015-1108/sinais-stubborn-insurgency

43 Under Usama bin Ladens lederskap var al-Qaida forsiktig med å gi merkenavnet sitt til lokale grupper som søkte anerkjennelse og samarbeid i frykt for at lokale splittelser, rivalisering og manglende dedikasjon til global jihadisme kunne svekke al-Qaidas kampsak. Se f.eks. "Letters from Abbottabad: Bin Laden sidelined?” CTC Report 3. mai 2012. Hentet fra ctc.usma.edu/posts/letters-from-abbottabad-binladin-sidelined

44 For en drøfting av skiftet fra jihadistiske webfora til sosiale mediaplattformer, se f.eks. Aaron Zelin, "The State of Global Jihad Online”, New America Foundation Report, 4. februar 2013. Hentet fra newamerica.org/international-security/ policy-papers/the-state-of-global-jihad-online/; og Cole Bunzel, "Are the Jihadi Forums Flagging? An Ideologue's Lament”, Jihadica.com 20. mars 2013. Hentet fra jihadica.com/are-the-jihadi-forums-flagging-anideologue\%E2\%80\%99s-lament/

45 USA tilbød direkte støtte til den etiopiske okkupasjonen av Somalia mellom senhøstes 2006 og våren 2009. Hjelpen tok ulike former: militær bistand, finansiell og diplomatisk støtte. Se f.eks. "U.S. support key to Ethiopia's invasion", USAToday 7. januar 2007. Hentet fra usatoday30.usatoday.com/ news/world/2007-01-07-ethiopia_x.htm; og Abdi Ismail Samatar, "Ethiopian Invasion of Somalia, US Warlordism \& AU Shame”, Review of African Political Economy 34, nr. 111 (2007): 155-165

46 Det faktum at arabisk er det dominerende, men ikke eneste, språket i bruk på disse jihadistforaene kan antakelig forklare hvorfor Talibans kamp ikke lenger ble prioritert. Talibangerilajen har for øvrig sine egne nettsider på flere språk og egne nettbaserte propagandakanaler.

47 For et motsatt syn, se Martha Crenshaw, "There Is No Global Jihadist 'Movement”, The Atlantic 11. mars 2015. Hentet fra 
theatlantic.com/international/archive/2015/03/there-is-noglobal-jihadist-movement/387502/

48 I juli 2016 ble Nusra-fronten omdøpt til Jabhat Fath al-Sham eller "Erobringsfronten for Levanten". Antakelig for å tilrettelegge for samarbeid med andre syriske opprørere erklærte gruppen at de ikke lenger hadde noen "tilknytning til eksterne enheter”, underforstått al-Qaida. I realiteten ser det imidlertid ut til at al-Qaida har bifalt Nusra-frontens omdøping og at båndene til al-Qaida ikke har blitt kuttet. Gruppens leder, Jawlani, har f.eks. rost Zawahiri og hans nestkommanderende for deres "velsignede lederskap". Se f.eks. "Syrian Nusra Front announces split from al-Qaeda", BBC.co.uk 29. juli 2016. Hentet fra bbc.com/news/worldmiddle-east-36916606; og "Analysis: Al Nusrah Front rebrands itself as Jabhat Fath Al Sham", Long War Journal 28. juli 2016. Hentet fra http://www.longwarjournal.org/ archives/2016/07/analysis-al-nusrah-front-rebrands-itself-asjabhat-fath-al-sham.php

49 Denne vurderingen bygger på observasjoner fra flere regioner. For eksempel i tilfellet AQIM i Vest-Afrika har man observer at " $[t]$ he increasing frequency of AQIM attacks and their timing, which has often coincided with IS assaults, suggests the group is trying to ensure it is not out-done by the more radical agenda of IS. The Bamako attack, for example, came just 10 days after the IS Paris attacks in November 2015; and the Ouagadougou attack occurred almost immediately after IS carried out an attack in Jakarta, the group's first assault in Southeast Asia." Sitert i Jessica Moody. "Foreign Assets Under Threat: Is AQIM Preparing an In Amenas-Style Attack?" Terrorism Monitor 14, nr. 14 (2016): 7-10. Hentet fra jamestown.org/uploads/media/

TM_Vol_14_Issue_03.pdf

50 Disse inkluderer IMU, Kaukasus-Emiratet, og Boko Haram.

51 Forholdet mellom al-Qaida og Taliban var beheftet med mange selvmotsigelser og spenninger. Se en autorativ fremstilling av dette forholdet i Anne Stenersen, "Brothers in Jihad: Explaining the Relationship between al-Qaida and the Taliban, 1996-2001”. Oslo: University of Oslo, Dr.Philos dissertation, 2012.

52 Jamfør sitatet: "Al Qaeda has never shown much interest in taking or holding territory in order to set up an Islamic state and govern". Hentet fra Daniel Byman \& Jennifer Williams, "ISIS vs. Al Qaeda: Jihadism's Global Civil War", The National Interest 24. februar 2015. Hentet fra nationalinterest.org/feature/isis-vs-al-qaeda-jihadism \%E2\%80\%99s-global-civil-war-12304

53 Proto-staten i nordlige Nigeria (se figur n5) ble etablert av Boko Haram, antakelig med minimal innblanding fra ISIS.

54 For en definisjon av jihadistdiaspora, se note 3.

55 Dette argumentet er drøftet i mer detalj i boken Brynjar Lia, Globalization and the Future of Terrorism: Patterns and Predictions. London \& New York: Routledge, 2005.

56 Hovedelementene bak al-Qaidas globale appell diskuteres i Brynjar Lia, "Al-Qaida's Appeal: Understanding its Unique
Selling Points", Perspectives on Terrorism 2, nr. 8 (2008): 310. Hentet fra terrorismanalysts.com/pt/index.php/ pot/article/view/44/html

57 Dette temaet drøftes i artikkelen Brynjar Lia, "The Jihadi Movement and Rebel Governance: A Reassertion of a Patriarchal Order?”, Die Welt des Islams (antatt til 2017).

58 Skjermdump hentet fra følgende to ISIS Libya-videoer: "To Establish the Religion - Wilayat Tarabulus", datert 30. mars 2016. Hentet fra jihadology.net/2016/03/30/newvideo-message-from-the-islamic-state-to-establish-thereligion-wilayat-\%E1\%B9\%ADarabulus/; og "And What Is To Come Will Be More Devastating and Bitter - Wilayat Tarabulus", datert 26. mars 2016. Hentet fra jihadology.net/ 2016/03/26/new-video-message-from-the-islamic-state-andwhat-is-to-come-will-be-more-devastating-and-bitterwilayat-\%E1\%B9\%ADarabulus

59 For en definisjon av jihadistdiaspora, se note 3. 